\title{
Chapter 4 \\ Extreme Colonizers and Rapid Profiteers: The Challenging World of Microorganisms That Attack Paper and Parchment
}

\author{
Flavia Pinzari and Beata Gutarowska
}

\begin{abstract}
Microorganisms form the backbone of life on Earth. Over billions of years, they have colonized and shaped every possible niche on the planet. Microbes have modelled both the land and the sea, and have created favourable conditions for multicellular organisms to thrive in. Our understanding of how microbial diversity is distributed across natural environments and how microbes affect ecosystems is constantly evolving as public databases are set up and new techniques based on massive sequencing are developed. The microbiome found in a particular anthropogenic environment is generally much less complex than those found in natural ones: there is less competition and the main actors are often linked to survival mechanisms regulated by a few limiting factors. Despite this simplicity, it is very difficult to link cause and effect when seeking to identify the role of individual organisms. In the case of biodeterioration of paper and parchment, even when analysing the individual components of a simple phenomenon, it is not always easy to understand the mechanisms at play. Works of art are unique objects and the elements that determine the arrival and establishment of one or more microorganisms and the direction that the biodeterioration process takes are always different. In some cases, however, there are common denominators and predictable mechanisms. The variables that come into play are examined below.
\end{abstract}

Keywords Ecology · Metabolomics · Niche - Colonization · Diagnostics · Mechanisms · Biodeterioration - Substrate - Succession · Metabolites · Enzymes · Indoor environment

\footnotetext{
F. Pinzari $(\bowtie)$

Institute for Biological Systems, National Research Council of Italy (CNR), Rome, Italy

Life Sciences Department, Natural History Museum, London, UK

e-mail: flavia.pinzari@cnr.it; f.pinzari@nhm.ac.uk

B. Gutarowska

Department of Environmental Biotechnology, Lodz University of Technology, Łódź, Poland

e-mail: beata.gutarowska@p.lodz.pl
} 


\section{Paper and Parchment as Food Sources for Microbes}

\subsection{Paper}

Paper serves as an excellent substrate for various heterotrophic organisms. It is, in fact, a source of organic carbon for many microorganisms, and when it is used in the manufacture of objects such as books, documents, prints, etc., it also contains several organic substances such as animal or vegetable glues, inks, pigments and fillers that can augment its biodegradability. These compounds can represent a nutritional source for many non-specialized microorganisms which, as they grow, prepare the substrate for a more specific and therefore more harmful attack by typically cellulolytic strains - that is, those capable of degrading the cellulose that constitutes the chief component of most papers.

The biodegradability of paper varies depending on different factors, such as the degree of polymerization of cellulose, the percentage ratio between the two types of cellulose (crystalline or amorphous), and the presence of chemical or mechanical pulp (lignin, for example, makes paper unattractive for many fungal species). Additionally, the type of glue used in the pulp or on the paper's surface, which can be of animal or plant origin (starch, gelatin, casein, rosin, etc.), has a significant effect because it can to a greater or lesser extent be either palatable or toxic to microorganisms. The nature of the fillers (e.g. talc, kaolin, calcium carbonate, etc.) used in the manufacture of paper, and possible surface treatments (e.g. colouration, satin-effects, etc.), can have a substantial effect on the outcome of an infection caused by microorganisms (Florian 2002; Pinzari et al. 2006).

Cellulose itself is a long linear chain of glucose. The polymer consists of anhydrous glucopyranose units joined by $\beta-1,4$ glycosidic bonds. A cellulose chain contains approximately 10,000 units of glucose with a molecular weight of approximately 1.5-2 million. The polymer chains are arranged parallel to each other and bind together by means of hydrogen bonds, forming fibrils. These fibrils can form a hydrophobic and very resistant crystalline structure. The enzymatic hydrolysis of crystalline cellulose typically requires the participation of three different enzymes: (1) an endo-1,4-3-glucanase (EC3.2.1.4) which breaks the molecule, randomly producing chains with free ends; (2) an eso-1,4-B-glucanase (EC3.2.1.91) that detaches cellobiose units, ß-glucose dimer, from the non-reducing ends of the linear chains; and (3) a B-glucosidase (EC3.2.1.21) that hydrolyses cellobiose to form glucose (Jayasekara and Ratnayake 2019).

The complete biodegradation of cellulose is carried out by microorganisms that possess all the above-mentioned enzymes; the enzymes operate in succession as a "cellulase complex" capable of breaking down the cellulose polymer into glucose monomers. There are, however, only a few organisms that show real cellulolytic activity: most of the species use simple, easily hydrolysable sugars. The various cellulolytic species produce a wide variety of isoenzymes that attack cellulose in different ways (Sterflinger and Pinzari 2012; El Bergadi et al. 2014; Oetari et al. 2016; Coronado-Ruiz et al. 2018; Jayasekara and Ratnayake 2019). For example, 
some fungal species do not possess all the enzymes that form the cellulase complex, and therefore exert an incomplete depolymerization effect on cellulose. Many fungi do not possess exoglucanase and act only on amorphous cellulose, leaving the crystalline component intact (Jayasekara and Ratnayake 2019). Bacteria possess cellulolytic enzyme systems that are just as effective and even more diversified than fungi.

The superiority of fungi in cellulose breakdown in comparison to unicellular organisms derives from their growth mode and ecology. Mycelium makes it possible for fungi to colonize a substrate more rapidly and to penetrate it by branching out within. In addition, fungal hyphae can readily move and mobilize the products of polymer degradation over considerable distances through the mycelial network (Szczepanowska et al. 2015). An important factor that influences the degree of cellulose decomposition is a relative lack of nitrogen. Natural cellulosic materials often have a C:N ratio of 100:1 or greater, so the addition of nitrogen is necessary for their decomposition. Consequently, the presence of glues containing proteins, such as gelatin or other nitrogen-rich molecules, increases the biodegradability of paper (Florian 2002).

Fungi that damage paper belong to a few genera that share some ecological traits which characterize them as species that are well suited to colonizing "indoor" environments. Such environments, although artificial, offer sufficient trophic niches to accommodate real trophic successions (Zyska 1997; Pinzari 2011, 2018; Mallo et al. 2017; Karakasidou et al. 2018; Koul and Upadhyay 2018; Lax et al. 2019). The species that attack books and archives are fungi that, in natural settings, are mainly found in soil and on decomposing plant and animal matter (saprophytic fungi) (Treseder and Lennon 2015; Hyde et al. 2019). They primarily feed on cellulose, starch and sugars, but some can also degrade chemically more complex substances such as lignin, keratin, glues and synthetic polymers (Ayu and Teja 2016; Brunner et al. 2018; Hyde et al. 2019). They are organisms that disperse through conidia and spores, which are easily transportable through the air or by insects.

Fungi can damage paper in different ways depending on the species concerned, growth conditions and the type of paper involved. The fungal hyphae can also penetrate cellulose fibrils, fragmenting them through mechanical action (Figs. 4.1, $4.2,4.3)$. They can also exploit cellulose as a substrate and cause sheets of paper to become fragile and cracked. Sometimes they release coloured metabolic substances of various kinds between the fibres that can stain sheets or induce chemical alterations, such as oxidation.

Melo et al. (2019) reviewed the known mechanisms behind the formation of stains on paper, the colourants commonly present in the stains and the main fungal species associated with both the production of coloured compounds and their ability to develop in paper. Among the most widespread and staining fungal pigments, melanins are particularly detrimental to books and objects of heritage. Melanins are often contained within the walls of fungi and typically accompany the growth of the hyphae across the cellulose network, infiltrating the structure of paper and causing dark stains that can remain deep in the body of the material (Szczepanowska et al. 


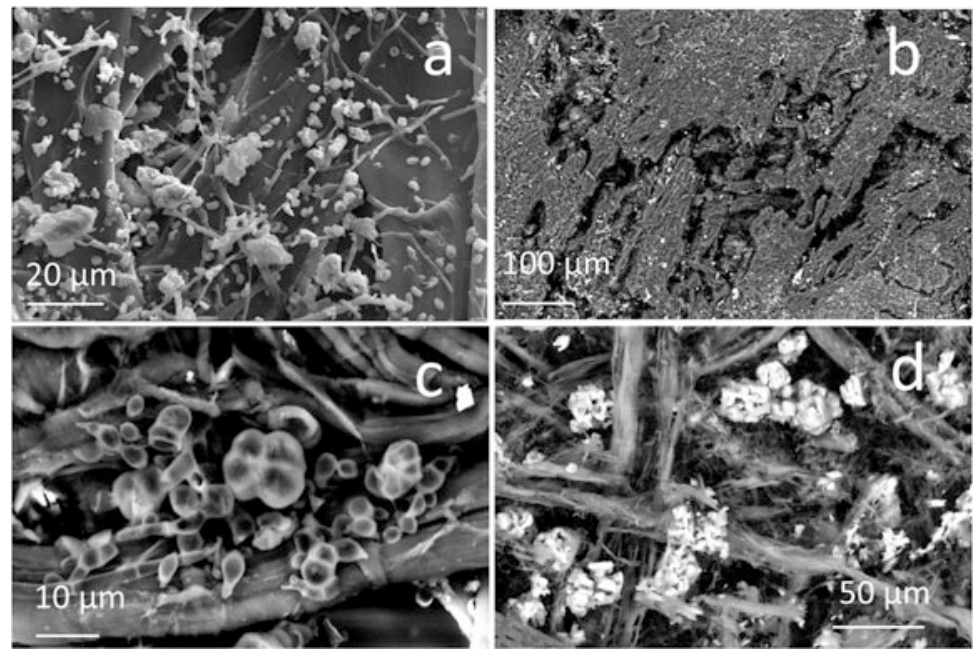

Fig. 4.1 Scanning Electron Microscopy images of parchment and paper samples affected by biodeterioration: (a) surface of a parchment leaf attacked by a fungus. The collagen fibres still appear intact, although fungal hyphae are attached to them. The fungus, in this case, is probably not using collagen as a carbon source, but it is feeding on other components of the material (i.e. waxes, glues, oils); (b) the surface of a parchment sample attacked by bacteria. Here there is visible evidence of the formation of cracks between the bundles of fibrils, and disintegration of the matrix that holds the fibrils together; (c) surface of a paper sample attacked by a fungus. Despite the fact that the organism has developed among the cellulose fibres producing abundant structures, the fibres still appear intact, indicating that the fungus is not using cellulose as a carbon source; (d) surface of a paper sample deeply infiltrated by a fungus that produced abundant acidic compounds, probably oxalic acids. The cellulose fibres appear broken and dissolved. These acidic compounds precipitate in the presence of calcium used in the manufacture of the paper; the precipitated crystals of calcium oxalate are visible as lighter structures in the image (they are brighter than cellulose because of the higher atomic mass of calcium, as revealed by a backscattered electron detector)

2015). Melanins are natural polymers characterized by a strong negative charge, high molecular weight and hydrophobic nature (Nosanchuk et al. 2015). They are produced through the oxidation and polymerization of phenolic/indolic precursors and in fungi they form insoluble pigments (eumelanins) that confer dark colourations and have several functional roles (for example: photoprotection, energy harvesting, heat gain, thermoregulation, and metal scavenging) (Cordero and Casadevall 2017). Colour and concentration of melanins can differ in one and the same microorganism depending on growth conditions, the availability of nutrients and the properties of the substrate. Accordingly, the same fungus can produce very different stains on different paper stocks (Pinzari et al. 2006). This wide variability in colour production also occurs in pigments other than melanin. According to Melo et al. (2019), the colourants predominantly produced by paper-colonizing fungi are hydroxyanthraquinoid (HAQN) pigments. These can be yellow and red or orange, and when widely distributed in paper can change in shade and intensity depending on the local $\mathrm{pH}$ and the presence of salts (Figs. 4.1, 4.2, 4.3). In the literature, the 

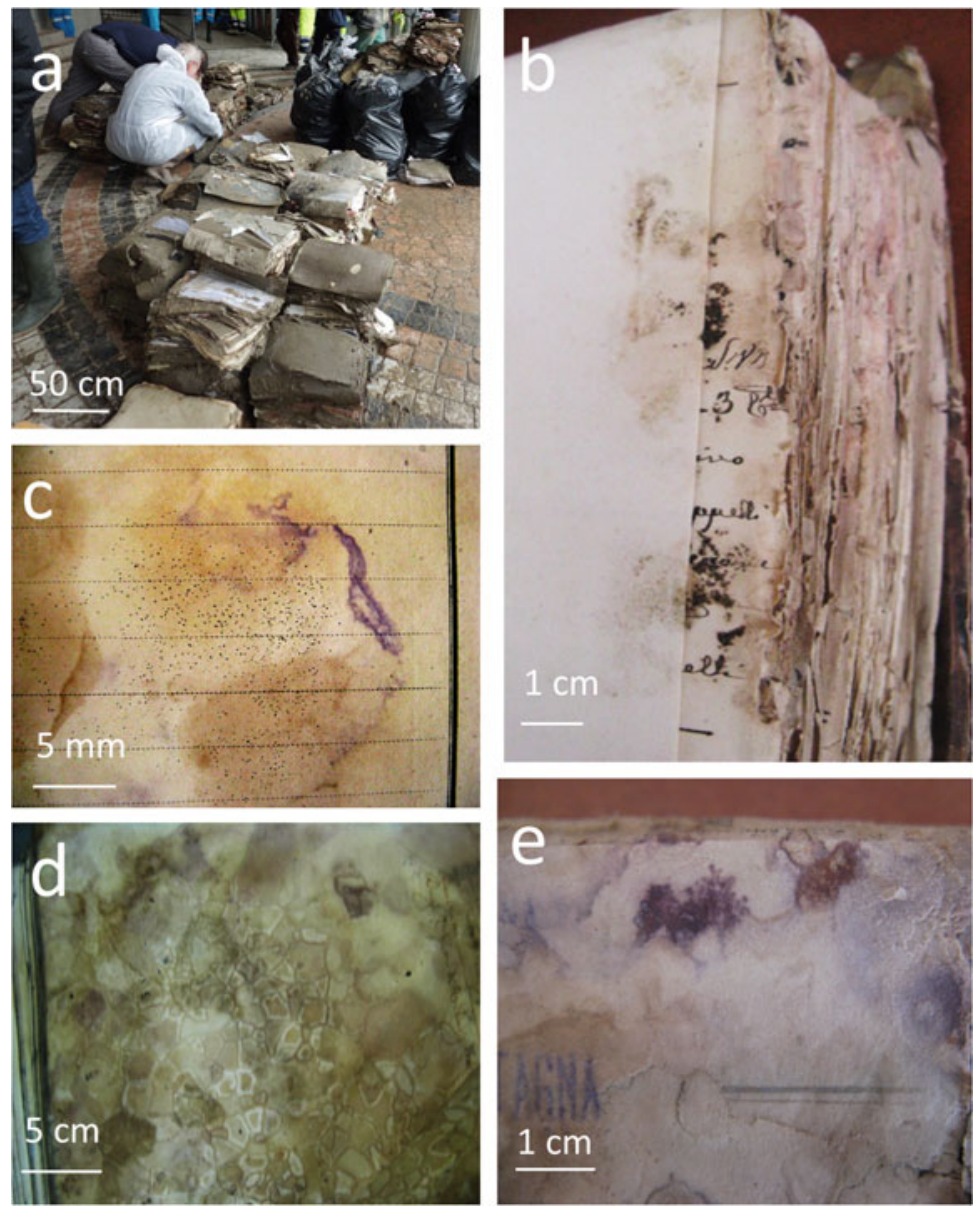

Fig. 4.2 Documents attacked by microorganisms after a wetting event. Paper materials, once soaked with water, are highly susceptible to degradation by different species of microorganisms whose spores normally inhabit the air and dust of indoor and outdoor environments; (a) the salvage of bibliographic material from a library following a flood (Aulla 2011 flood, MS, Italy, photo by Piero Colaizzi, ICRCPAL, Rome); (b, c, d, e) books and documents made of paper attacked by microorganisms (fungi and bacteria). The species of fungi and actinomycetes (filamentous bacteria) that take advantage of a sudden availability of water are usually very competitive, able to secrete enzymes, organic acids and pigments, and to develop rapidly at the expense of the substratum, which, in the case of paper, becomes fragile, cracked, stained and mottled with abundant fruiting bodies (which carry the spores or the conidia). In particular, figure (d) shows a pattern of stains that form a sort of grid, where the sides of each block are the sign of competition between two different species of fungi, which at the point of contact produce more pigments and metabolic substances aimed at repelling the opponent in order to occupy more space in the material 

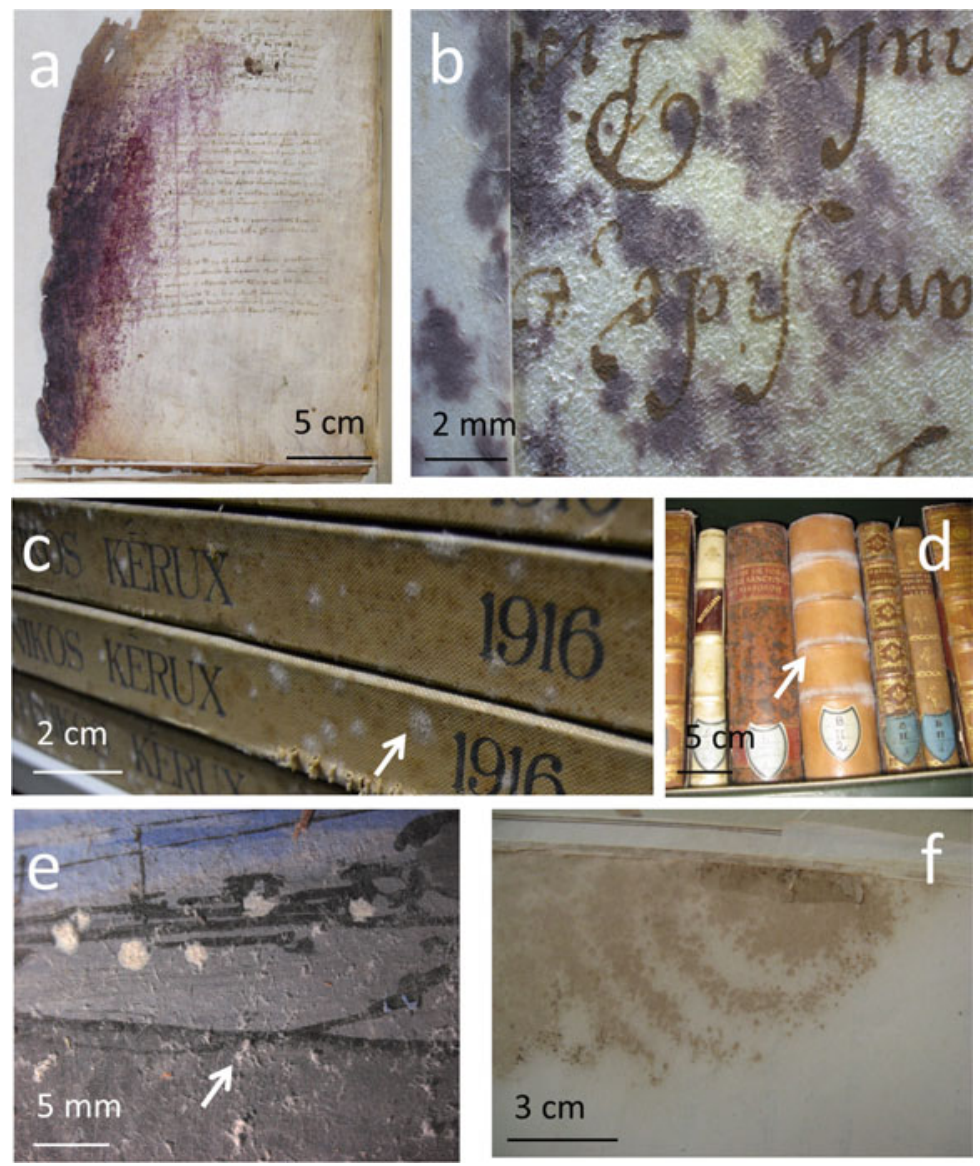

Fig. 4.3 Library and archival materials attacked by s-selected microorganisms. When the environmental conditions are permanently hostile to the development of most of the microorganisms, some species that are not very competitive but are highly evolved to withstand certain types of stress and limitations, establish themselves on the materials, sometimes giving rise to massive colonization phenomena; (a, b) purple stains on parchment caused by halophilic microorganisms, which are associated with the salt used in the manufacturing process, which can remain dormant for many years among collagen fibres; (c, d) the typical manifestation of a widespread infection of the fungus Eurotium halophilicum in a library. This fungus develops slowly in environments where conservation conditions are good, but takes advantage of the absence of ventilation or other microenvironmental conditions that favour water condensation on some materials; (e) fungal efflorescence on the gypsum-based preparatory layer and the mineral pigments that make up the illuminations on a parchment. Many microorganisms find an ideal niche in materials that are typically hostile to other species; (f) a peculiar oxidation pattern on a paper sheet affected by biodeterioration. The shape of the stains suggests the periodic growth of microorganisms probably capable of re-starting their growth from the hyphal tips in the presence of a recurring event (i.e. re-wetting or temperaturerelated) 
production of these colourants is often associated with the genera Aspergillus and Penicillium (Melo et al. 2019), which are also frequently found on stained paper.

\subsection{Parchment}

Parchment was the most commonly used writing material from the second century BC to the end of the Middle Ages, when it was substituted by paper in Europe. It is a thin material made from the skin of animals such as sheep, goats, lambs, pigs and calves. It differs from leather in that it is mainly limed rather than tanned. There were considerable differences in parchment manufacturing methods in different countries and historical periods. Even so, the preparation of parchment involved always the cleaning and mechanical removal of hair by scraping the flayed skin, followed by desiccation of any remaining flesh using sodium or potassium chloride, adjustment of the $\mathrm{pH}$ by treatment with ammonium chloride or sulphate with lime, and the application of potash alum (Larsen 2002). Parchment books, depending on their date of manufacture and country of origin, were written using iron gall or carbon pigmented inks, or printed using resinous printing inks; they were frequently illuminated with a wide range of mineral and organic pigments, and embellished with metals such as gold or silver and their alloys. In maedieval times, egg white, natural oils and other materials were applied to the parchment to form a very smooth, highly polished surface for writing and illumination. Parchments were also used in the making of official and private documents (e.g. contracts, wills, genealogies, maps, etc.), often collected in composite volumes bound together by sewing with thread or ribbons, and sometimes with adhesives. The main chemical component of parchment is collagen, a natural biopolymer with a relative molecular mass of $350 \mathrm{kDa}$. Collagen is formed from a triple helix with random coil telo-peptides. Degradation of parchment is a complex process which involves the oxidative chemical deterioration of the amino acid chains and hydrolytic cleavage of the peptide backbone (Florian 2007).

Parchment is usually a very robust and durable material; it is particularly resistant to abrasion, tearing and other mechanical damage. Parchment is more resistant than paper to corrosive inks and acid degradation in general, owing to the alkaline agents used in the manufacturing process, such as lime and chalk. However, parchment is extremely hygroscopic, which makes it highly susceptible to infection by bacteria and moulds when exposed to elevated relative humidity.

Microorganisms with a proteolytic capacity include bacteria and fungi, even if the former possess more specific collagenases capable of digesting the proteins of the parchment through hydrolysis (Figs. 4.1, 4.3). Fungi, on the other hand, develop particularly at the expense of oils and waxes added during the manufacturing process (to make the parchment more flexible), although some species of proteolytic fungi can also utilize collagen as their sole carbon source (Florian 2002, 2007; Pinzari et al. 2012a, b; Lech 2016; Pinzari 2018). 
The microorganism species involved in the degradation of parchment can vary considerably with the chemical characteristics of the material, which can be very different depending on the origin of the animal, the part of it used and the manufacturing processes employed. The presence of fats lends parchment a certain degree of water repellency which largely speaking slows down biodeterioration processes. Lipid substances are rather resistant to biological degradation but become more susceptible if they are found as water supported emulsions or in the presence of additional nutritional sources that can easily be metabolized, such as simple sugars (Florian 2002, 2007; Pinzari et al. 2012a, b; Lech 2016; Pinzari 2018).

It has been observed that biodegradation typically starts on the side of the parchment corresponding to the "flesh" side of the skin. In the more advanced stages of degradation, the side bearing the grain (i.e. the "hair" side) is also attacked, where the collagen and elastin fibres form a denser network.

Initial studies on parchment deterioration indicated the Actinomycetes as the bacterial group that plays a major role in the deterioration of many kinds of historical documents and books supported on parchment. Actinomycetes are known to produce many types of enzyme, collagenases (proteases) in particular that are capable of destroying collagen through their hydrolytic activity (Blyskal et al. 2017). Many species are alkaliphiles and therefore develop on parchments (prepared with chalk). However, some more recent studies (Piñar et al. 2015a, b; Migliore et al. 2017, 2019) have highlighted some rather complex mechanisms driving parchment biodegradation, in which actinomycetes only represent some of the actors.

\section{The Fungal and Bacterial Species That Attack Paper and Parchment}

During their storage and utilization, paper and parchment can be colonized by numerous microorganisms, especially fungi and bacteria, including actinomycetes. Examples of microorganisms isolated from paper and parchment are presented in Tables 4.1 and 4.2.

In total, 85 fungal genera and 71 bacterial genera were identified in the book's constituent materials. Paper is a material that is susceptible to a larger number of colonizing microorganisms (80 genera of fungi and 59 genera of bacteria) than parchment (29 genera of fungi, 23 genera of bacteria). The development of modern molecular methods, chiefly NGS (next-generation sequencing), is greatly contributing to the discovery of new genera of microorganisms that colonize these materials. Molecular methods have identified an additional 40 genera of fungi (out of the 85 recognized so far) that inhabit paper but were not previously detected, since they cannot be cultured under laboratory conditions, and 58 genera of bacteria out of the 71 known up to the present. In the case of parchment, thanks to the use of molecular methods, an additional 15 genera of fungi and several taxa of unculturable bacteria have been discovered as frequent colonizers and potential spoilers of the material. It 
Table 4.1 Book materials (paper and parchment) contaminated with fungi, identified by means of culture-dependent and independent methods

Isolated from book materials identified by cultural dependent ${ }^{\mathrm{a}}$ and culture independent ${ }^{\mathrm{b}}$ methods

\begin{tabular}{|c|c|c|c|}
\hline Genera of fungi & Paper & Parchment & References \\
\hline Acremonium & $a, b$ & $a, b$ & \multirow{39}{*}{$\begin{array}{l}\text { Arai (2000), Borrego et al. (2012), El Bergadi et al. } \\
\text { (2014), Florian and Manning (2000), Gutarowska } \\
\text { (2016), Karakasidou et al. (2018), Karbowska- } \\
\text { Berent et al. (2014), Kraková et al. (2012, 2018), } \\
\text { Lech (2016), Michaelsen et al. (2009, 2010), Nol } \\
\text { et al. (2001), Nunes et al. (2015), Oetari et al. } \\
\text { (2016), Paiva de Carvalho et al. (2016), Piñar et al. } \\
\text { (2015a, b), Principi et al. (2011), Rakotonirainy } \\
\text { et al. (2007), Saada et al. (2018), Sato et al. (2014), } \\
\text { Szczepanowska et al. (2014), Szulc et al. (2018), } \\
\text { Tanney et al. (2015), Zotti et al. (2008, 2011), Zyska } \\
\text { (1997) }\end{array}$} \\
\hline Acrothecium & $\mathrm{a}$ & & \\
\hline Alternaria & $a, b$ & $a, b$ & \\
\hline Aspergillus & $a, b$ & $a, b$ & \\
\hline Aureobasidium & $a, b$ & $\mathrm{~b}$ & \\
\hline Beauveria & $\mathrm{b}$ & & \\
\hline Bjerkandera & $\mathrm{b}$ & & \\
\hline Blumeria & & $\mathrm{b}$ & \\
\hline Botryotrichum & $\mathrm{a}$ & & \\
\hline Botrytis & $\mathrm{a}$ & & \\
\hline Byssochlamys & $\mathrm{b}$ & & \\
\hline Capnobotryella & $\mathrm{b}$ & & \\
\hline Ceratocystis & $\mathrm{a}$ & & \\
\hline Chaetomium & $a, b$ & $a, b$ & \\
\hline Chalastospora & $\mathrm{a}, \mathrm{b}$ & & \\
\hline Cladonia & $\mathrm{b}$ & & \\
\hline Chloridium & $\mathrm{a}$ & & \\
\hline Chrysosporium & $\mathrm{a}$ & & \\
\hline Cladobotryum & $\mathrm{a}$ & & \\
\hline Cladosporium & $a, b$ & $\mathrm{a}, \mathrm{b}$ & \\
\hline Coniosporium & $\mathrm{a}$ & $\mathrm{b}$ & \\
\hline Curvularia & $\mathrm{a}$ & & \\
\hline Diaporthe & $\mathrm{b}$ & & \\
\hline Diploöspora & & $\mathrm{a}, \mathrm{b}$ & \\
\hline Doratomyces & $\mathrm{a}$ & & \\
\hline Engyodontium & & $\mathrm{b}$ & \\
\hline Epicoccum & $a, b$ & $a, b$ & \\
\hline Erysiphales & $\mathrm{b}$ & & \\
\hline Eurotium & $\mathrm{a}, \mathrm{b}$ & $\mathrm{b}$ & \\
\hline Fusarium & $\mathrm{a}$ & $\mathrm{a}$ & \\
\hline Geomyces & $\mathrm{a}$ & & \\
\hline Geosmithia & $\mathrm{a}$ & & \\
\hline Geotrichum & $\mathrm{a}$ & & \\
\hline Gleotinia & $\mathrm{b}$ & & \\
\hline Gliocladium & $\mathrm{a}$ & & \\
\hline Graphiopsis & $\mathrm{b}$ & & \\
\hline Gymnoascus & $\mathrm{a}$ & & \\
\hline Haplographium & $\mathrm{a}$ & & \\
\hline Helicostylum & $\mathrm{a}$ & & \\
\hline
\end{tabular}


Table 4.1 (continued)

Isolated from book materials identified by cultural dependent ${ }^{\mathrm{a}}$ and culture independent $\mathrm{t}^{\mathrm{b}}$ methods

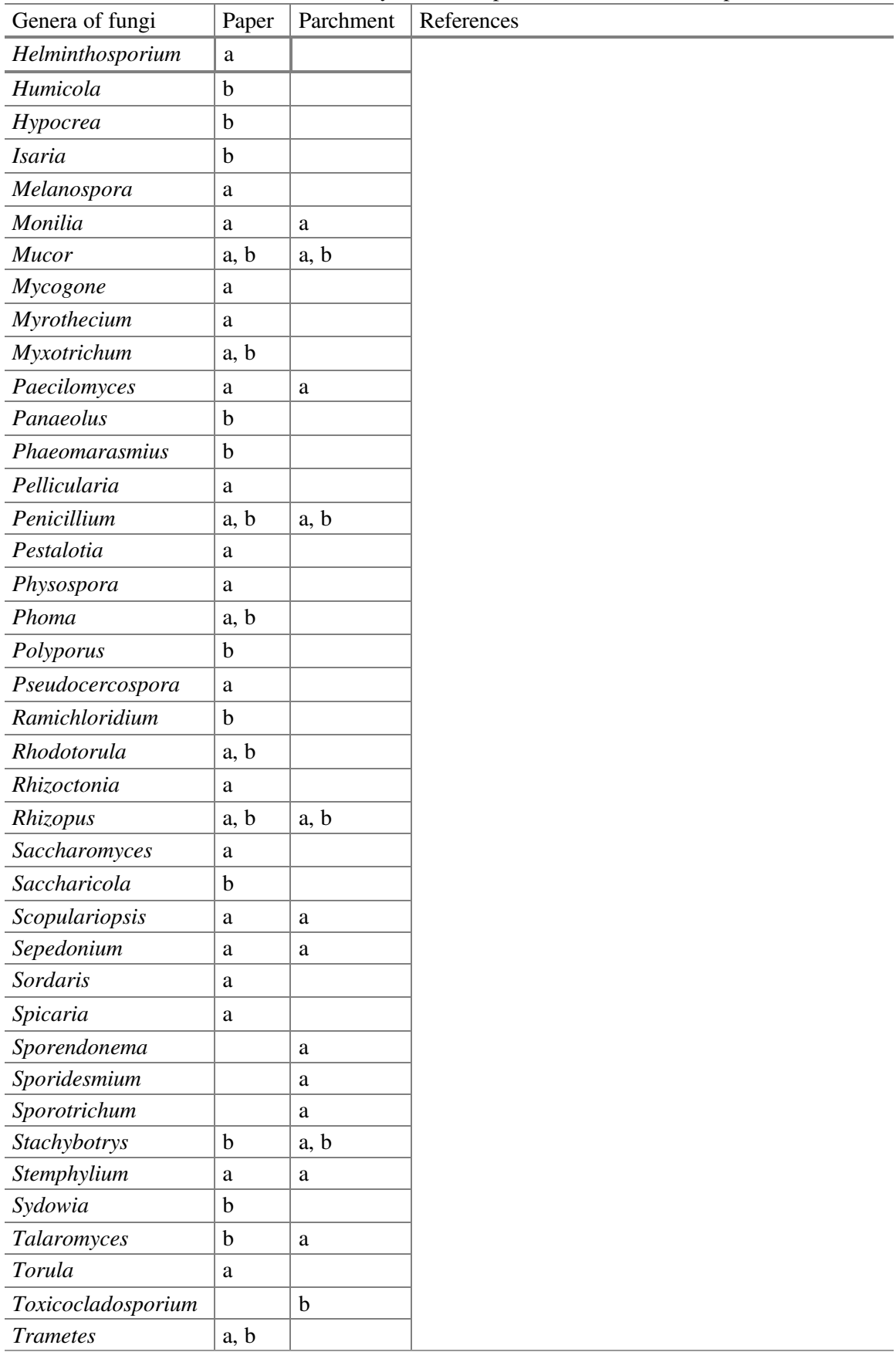


Table 4.1 (continued)

Isolated from book materials identified by cultural dependent ${ }^{\mathrm{a}}$ and culture independent ${ }^{\mathrm{b}}$ methods

\begin{tabular}{l|l|l|l}
\hline Genera of fungi & Paper & Parchment & References \\
\hline Trichocladium & a & & \\
\hline Trichoderma & a, b & a, b & \\
\hline Trichosporum & b & a, b & \\
\hline Trichothecium & a & a & \\
\hline Ulocladium & a, b & \multicolumn{1}{|l}{} \\
\hline Verticillium & a & a & \\
\hline Wallemia & b & & \\
\hline
\end{tabular}

is therefore necessary to verify the mechanisms behind paper and parchment biodeterioration in which both bacteria and fungi are at play, because as yet knowledge of the role played by different groups of microorganisms in the material's spoilage is limited. It is widely believed that fungi are the main actors in paper biodeterioration, while in the case of parchment the most effective taxa in biodegradation processes are bacteria. However, recent evidence indicates that mechanisms are more complex and that often the co-occurrence of bacteria and fungi is the norm, with clear implications for the choice of treatments to be applied during the conservation of materials. In the case of fungi, culture-dependent methods are still widely used in the laboratory, and research results indicate that $58 \%$ of fungal species can be identified using culturing methods, $26 \%$ using molecular methods and 15\% using both methods (Gutarowska 2016).

So far though, only a few genera of microorganisms inhabiting book materials have been identified using both methods (culture-dependent and molecular), with just 18 and 12 genera of fungi, on paper and parchment, respectively, and 8 taxa of bacteria on paper that have been identified using both approaches. Microbial community analysis using the NGS method makes it possible to detect higher biodiversity than the culture-dependent approach yields (Kraková et al. 2018) and some early culture-independent approaches based on cloning (Michaelsen et al. 2006, 2009, 2010; Pangallo et al. 2009). Being in possession of exhaustive lists of the species of fungi and bacteria that attack various library and archival materials, and different parts of the objects in various types of environment, will certainly aid us in better understanding colonization and deterioration mechanisms and will facilitate statistical analysis of the frequency with which certain species occur. So far, this type of study has been restricted by the limited number of culturable organisms. However, in order to know which organisms are responsible for causing damage, it is necessary to have not only a list of candidates but also to identify their impact on the materials and the metabolites they produce. Tables 4.3 and 4.4 report the most common microorganisms inhabiting paper and parchment, for which biodeterioration mechanisms have been described. 
Table 4.2 Book materials (paper and parchment) contaminated with bacteria, identified by means of culture-dependent and independent methods

Isolated from book materials identified by cultural dependent ${ }^{\mathrm{a}}$ and culture independent ${ }^{\mathrm{b}}$ methods

\begin{tabular}{|c|c|c|c|}
\hline Genera of bacteria & Paper & Parchment & References \\
\hline Actinomycetospora & & $\mathrm{a}$ & \\
\hline Actinomycetospora & $\mathrm{b}$ & & \multirow{38}{*}{$\begin{array}{l}\text { Michaelsen et al. (2010), Kraková et al. (2012), Piñar } \\
\text { et al. (2015a, b), Lech (2016), Karakasidou et al. } \\
\text { (2018), Gutarowska (2016), Kraková et al. (2018), } \\
\text { Szulc et al. (2018), Migliore et al. (2019) }\end{array}$} \\
\hline Actinoalloteichus & $\mathrm{b}$ & & \\
\hline Amycolatopsis & $\mathrm{b}$ & & \\
\hline Aerococcus & $a, b$ & & \\
\hline Aeromonas & $\mathrm{b}$ & & \\
\hline Acinetobacter & $\mathrm{b}$ & $a, b$ & \\
\hline Alkanindiges & $\mathrm{b}$ & & \\
\hline Alloiococcus & $\mathrm{b}$ & & \\
\hline Arthrobacter & $\mathrm{b}$ & $\mathrm{b}$ & \\
\hline Bacillus & $a, b$ & $\mathrm{a}, \mathrm{b}$ & \\
\hline Brevibacillus & $\mathrm{b}$ & & \\
\hline Brevibacterium & $\mathrm{b}$ & & \\
\hline Brevundimonas & $\mathrm{b}$ & & \\
\hline Burkholderia & $\mathrm{b}$ & & \\
\hline Caedibacter & & $\mathrm{b}$ & \\
\hline Cellvibrio & $\mathrm{b}$ & & \\
\hline Carnobacterium & $\mathrm{b}$ & & \\
\hline Clostridium & $\mathrm{b}$ & $\mathrm{b}$ & \\
\hline Corynebacterium & $\mathrm{b}$ & & \\
\hline Curtobacterium & $\mathrm{b}$ & & \\
\hline Dehalobacter & $\mathrm{b}$ & & \\
\hline Delfia & $\mathrm{b}$ & & \\
\hline Desulfotomaculum & $\mathrm{b}$ & & \\
\hline Enterococcus & $\mathrm{b}$ & & \\
\hline Erwinia & $\mathrm{b}$ & & \\
\hline Facklamia & $\mathrm{b}$ & & \\
\hline Fructobacillus & $\mathrm{b}$ & $\mathrm{b}$ & \\
\hline Geomicrobium & & $\mathrm{b}$ & \\
\hline Gluconobacter & $\mathrm{b}$ & & \\
\hline Halobacillus & & $\mathrm{b}$ & \\
\hline Halobacterium & & $\mathrm{b}$ & \\
\hline \multicolumn{3}{|l|}{ Halomonas } & \\
\hline Ignavigranum & $\mathrm{b}$ & & \\
\hline Jeotgalicoccus & $\mathrm{b}$ & $\mathrm{b}$ & \\
\hline Kocuria & $\mathrm{a}, \mathrm{b}$ & & \\
\hline Lactobacillus & $\mathrm{b}$ & $\mathrm{b}$ & \\
\hline Legionella & & $\mathrm{b}$ & \\
\hline Leuconostoc & $\mathrm{b}$ & & \\
\hline
\end{tabular}


Table 4.2 (continued)

Isolated from book materials identified by cultural dependent ${ }^{\mathrm{a}}$ and culture independent ${ }^{\mathrm{b}}$ methods \begin{tabular}{l|l|l|l}
\hline Genera of bacteria & Paper & Parchment & References
\end{tabular}

\begin{tabular}{l|l|l}
\hline Masillia & $\mathrm{b}$ & \\
\hline Methylococcus & & \\
\hline
\end{tabular}

Microbacterium $\mathrm{a}, \mathrm{b}$

Micrococcus $\quad$ b

\begin{tabular}{l|l|l}
\hline Micromonospora & $\mathrm{b}$ & \\
\hline Mycobacterium & $\mathrm{b}$ &
\end{tabular}

\begin{tabular}{|c|c|}
\hline Mycobacterium & $\mathrm{b}$ \\
\hline Methylobacterium & \\
\hline
\end{tabular}

\begin{tabular}{l|l}
\hline Natronocella & $\mathrm{b}$ \\
\hline
\end{tabular}

\begin{tabular}{l|l|l|}
\hline Nocardiopsis & & $\mathrm{b}$ \\
\hline Pediococcus & $\mathrm{b}$ & \\
\hline Paenisporosarcina & $\mathrm{b}$ & $\mathrm{b}$
\end{tabular}

\begin{tabular}{l|l|l}
\hline Paenisporosarcina & $\mathrm{b}$ & $\mathrm{b}$
\end{tabular}

\begin{tabular}{l|l|l|}
\hline Pseudomonas & $\mathrm{b}$ & $\mathrm{b}$ \\
\hline Pseudonocardia & $\mathrm{b}$ & \\
\hline Psychrobacillus & $\mathrm{a}$ & \\
\hline Psychrobater & $\mathrm{b}$ & $\mathrm{b}$
\end{tabular}

\begin{tabular}{l|l|l}
\hline Psychrobacter & b & b \\
\hline Propionibacterium & b & b
\end{tabular}

\begin{tabular}{l|l|l}
\hline Propionibacterium & $\mathrm{b}$ & $\mathrm{b}$
\end{tabular}

\begin{tabular}{l|l|l|}
\hline Ralstonia & $\mathrm{b}$ & \\
\hline Rhodococcus & $\mathrm{b}$ & \\
\hline Rhiobium & & $\mathrm{b}$ \\
\hline
\end{tabular}

\begin{tabular}{l|l|l}
\hline Rhizobium & & $\mathrm{b}$ \\
\hline Saccharopolyspora & $\mathrm{b}$ & \\
\hline Serratia & $\mathrm{b}$ & \\
\hline Sporosarcina & $\mathrm{a}, \mathrm{b}$ & \\
\hline Staphylococcus & $\mathrm{a}, \mathrm{b}$ & $\mathrm{b}$ \\
\hline Stenotrophomonas & $\mathrm{b}$ & \\
\hline Streptococcus & $\mathrm{a}$ & \\
\hline Streptomyces & $\mathrm{b}$ & \\
\hline Sulfobacillus & $\mathrm{b}$ & $\mathrm{b}$ \\
\hline Vibrio & $\mathrm{b}$ & \\
\hline Virgibacillus & $\mathrm{b}$ &
\end{tabular}

\section{Arrival, Colonization and Affirmation}

The colonization of libraries, archives and other repositories is accomplished by organisms with particular characteristics which allow them to adopt suitable dispersion mechanisms. Water and nutrients are usually only sporadically available in artificial environments, which makes them rather fragmented and variable (Lazaridis et al. 2018). Fungal hyphae are better adapted than bacteria to cross nutrient-and water-deprived areas when searching for resources (Ritz 1995), thanks to their 
Table 4.3 Microbial colonizers of paper and biodeterioration mechanisms

\begin{tabular}{|c|c|c|}
\hline $\begin{array}{l}\text { Microorganisms colonizing } \\
\text { paper }\end{array}$ & $\begin{array}{l}\text { Mechanisms of } \\
\text { biodeterioration }\end{array}$ & References \\
\hline \multicolumn{3}{|l|}{ Fungi } \\
\hline $\begin{array}{l}\text { Acremonium sp. } \\
\text { Alternaria sp. (A. alternata, } \\
\text { A. infectoria) } \\
\text { Aspergillus sp. (A. awamori, } \\
\text { A. clavatus, A. flavus, } \\
\text { A. fumigatus, A. jensenii, } \\
\text { A. niger, A. penicillioides, } \\
\text { A. pulvericola, A. ruber, } \\
\text { A. versicolor) } \\
\text { Chalastospora sp. (- } \\
\text { Ch. gossypii) } \\
\text { Cladonia sp. } \\
\text { Cladosporium sp. } \\
\text { Epicoccum sp. (E. nigrum) } \\
\text { Eurotium sp. (E. herbariorum) } \\
\text { Penicillium sp. (P. citrinum, } \\
\text { P. chrysogenum, P. oxalicum, } \\
\text { P. rubens) } \\
\text { Phoma } \text { sp. } \\
\text { Pseudocercospora } \\
\text { sp. (P. chiangmaiensis) } \\
\text { Trametes sp. (T. ochracea) } \\
\text { Trichoderma } \\
\text { sp. (T. longibrachiatum) }\end{array}$ & $\begin{array}{l}\text { Production of organic acids } \\
\text { and other metabolites, which } \\
\text { can react with elements on } \\
\text { paper leading to oxidative } \\
\text { reaction and formation of } \\
\text { brown foxing stains. } \\
\text { Oxidation of cellulose. } \\
\text { Reaction of cellulose degrada- } \\
\text { tion products with amino acids, } \\
\text { auto-oxidation of lipids present } \\
\text { in the fungal mycelium } \\
\text { (Maillard reaction). }\end{array}$ & $\begin{array}{l}\text { Florian (1996), Arai (2000), } \\
\text { Corte et al. (2003), Choi } \\
\text { (2007), Zotti et al. (2008), } \\
\text { Karbowska-Berent et al. } \\
\text { (2014), Piñar et al. (2015a), } \\
\text { Modica et al. (2016), Szulc } \\
\text { et al. (2018), Saada et al. } \\
\text { (2018), Oetari et al. (2016), } \\
\text { Karakasidou et al. (2018) }\end{array}$ \\
\hline $\begin{array}{l}\text { Alternaria sp. (A. solani) } \\
\text { Aspergillus sp. (A. carneus, } \\
\text { A. flavus, A. fumigatus, } \\
\text { A. nidulans, A. niger, A. } \\
\text { oryzae, A. melleus, } \\
\text { A. penicillioides, } \\
\text { A. sclerotium, A. tamarii, } \\
\text { A. terreus, A. ustus, } \\
\text { A. versicolor), } \\
\text { Cladosporium } \\
\text { sp. (C. cladosporioides, } \\
\text { C. sphaerospermum), } \\
\text { Chaetomium sp. (- } \\
\text { Ch. globosum) } \\
\text { Eurotium sp. (E. repens, } \\
\text { E. rubrum, E. amstelodami, } \\
\text { E. halophilicum, } \\
\text { E. herbariorum) } \\
\text { Penicillium } \\
\text { sp. (P. chrysogenum, } \\
\text { P. citrinum, P. commune, } \\
\text { P. funiculosum, P. islandicum, } \\
\text { P. notatum, P. purpurogenum, } \\
\text { P. spinulosum) }\end{array}$ & $\begin{array}{l}\text { Production of stains-polyke- } \\
\text { tide quinones, carotenoids } \\
\text { (main brown 54\%, black } 23 \% \text {, } \\
\text { green 6\%, yellow } 7 \% \text {, purple } \\
5 \% \text { pink } 5 \% \text { ) }\end{array}$ & Melo et al. (2019) \\
\hline
\end{tabular}


Table 4.3 (continued)

\begin{tabular}{|c|c|c|}
\hline $\begin{array}{l}\text { Microorganisms colonizing } \\
\text { paper }\end{array}$ & $\begin{array}{l}\text { Mechanisms of } \\
\text { biodeterioration }\end{array}$ & References \\
\hline \multicolumn{3}{|l|}{$\begin{array}{l}\text { Trichoderma spp. (T. koningii, } \\
\text { T. pseudokoningii, } \\
\text { T. citrinoviride) } \\
\text { Others }\end{array}$} \\
\hline \multicolumn{3}{|l|}{ Bacteria } \\
\hline $\begin{array}{l}\text { Ralstonia sp. } \\
\text { Delfia } \mathrm{sp} .\end{array}$ & $\begin{array}{l}\text { Enzymatic degradation of } \\
\text { chemicals used in papermak- } \\
\text { ing, production of coloured } \\
\text { slimes, ability to produce dif- } \\
\text { fusible brown pigments. }\end{array}$ & $\begin{array}{l}\text { Väisänen et al. (1998), Szulc } \\
\text { et al. (2018) }\end{array}$ \\
\hline $\begin{array}{l}\text { Pseudomonas sp. (P. stutzeri) } \\
\text { Burkholderia sp. (B. cepacia) }\end{array}$ & $\begin{array}{l}\text { Enzymatic degradation of } \\
\text { starch, casein, carboxymethyl } \\
\text { cellulose, ability to produce } \\
\text { diffusible yellow pigments. }\end{array}$ & Szulc et al. (2018) \\
\hline $\begin{array}{l}\text { Bacillus sp. } \\
\text { Brevibacillus sp. } \\
\text { Lysinibacillus sp. }\end{array}$ & $\begin{array}{l}\text { Enzymatic degradation of } \\
\text { starch, casein, cellulose. }\end{array}$ & $\begin{array}{l}\text { De Paolis and Lippi (2008), } \\
\text { Szulc et al. (2018) }\end{array}$ \\
\hline
\end{tabular}

ability to mechanically penetrate substrates and translocate nutrients. Active and passive dispersal mechanisms can produce very different results in indoor environments. Fungi and bacteria populate the airborne dust of indoor environments as resting spores or living propagules. These organisms can be introduced to buildings by different sources or be generated from "amplification sites". Damp walls, ventilation systems, spoiled food or rotting materials can host bacterial or fungal biofilms and act as rich sources of airborne contamination (Wang et al. 2016; Liu et al. 2018). The number of spores deriving from a contaminated material can vary considerably with the biology and ecology of individual species, and can also be influenced by chance events. However, not all microbes have evolved for air dispersion; there are several other mechanisms which favour the microbial colonization of new "niches". Some of the pests that attack organic materials in libraries and archives, such as wood, paper, leather and parchment, can feed on moulds or cohabit with them, and act as active or passive means of dispersal. Insect-mediated fungal dispersion has been widely documented in natural environments (Jacobsen et al. 2018), but it also occurs in indoor environments. Some indoor species such as silverfish (family Lepismatidae), booklice (family Liposcelididae) and mites (i.e. family Pyroglyphidae, genus Dermatophagoides) are often directly correlated to the moulds infecting materials (Green and Farman 2015) in mutually beneficial circumstances. In fact, the metabolic water produced by insects, their droppings and debris constitute an ideal substrate for fungal development (Pinzari and Montanari 2008, 2011). Humans constitute another factor in the contamination of materials and the dispersion of microorganisms.

Traces of the human microbiome are typically present on materials and thanks to molecular analysis this is becoming increasingly apparent, as the list of 
Table 4.4 Microbial colonizers of parchment and biodeterioration mechanisms

\begin{tabular}{|c|c|c|}
\hline $\begin{array}{l}\text { Microorganisms } \\
\text { colonizing paper }\end{array}$ & Mechanisms of biodeterioration & References \\
\hline \multicolumn{3}{|l|}{ Fungi } \\
\hline $\begin{array}{l}\text { Alternaria } \text { sp. } \\
\text { (A. alternata) } \\
\text { Aspergillus } \\
\text { sp. (A. versicolor, A. niger, } \\
\text { A. fumigatus) } \\
\text { Aureobasidium } \\
\text { sp. (A. pullulans) } \\
\text { Cladosporium sp. } \\
\text { (C.cladosporioides) } \\
\text { Chaetomium sp. } \\
\text { (Ch. globosum) } \\
\text { Epicoccum sp. (E. nigrum) } \\
\text { Eurotium sp. } \\
\text { (E. halophilicum) } \\
\text { Mucor } \text { sp. } \\
\text { Penicillium } \\
\text { sp. (P. chrysogenum, } \\
\text { P. citrinum, P. glabrum, } \\
\text { P. spinulosum) } \\
\text { Rhizopus sp. } \text { (R. oryzae) } \\
\text { Trichoderma } \\
\text { sp. (T. pseudokoningii, } \\
\text { T. longibrachiatum) } \\
\text { Talaromyces } \\
\text { sp. (T. spectabilis) }\end{array}$ & $\begin{array}{l}\text { Enzymatic degradation of collagen, } \\
\text { structural damage. } \\
\text { Production of stains (different col- } \\
\text { ours). } \\
\text { Production of organic acids } \\
\text { (fumaric, lactic, malic). }\end{array}$ & $\begin{array}{l}\text { Piñar et al. (2015b, c), Lech } \\
\text { (2016), Paiva de Carvalho } \\
\text { et al. (2016), Saada et al. } \\
\text { (2018) }\end{array}$ \\
\hline
\end{tabular}

\begin{tabular}{|c|c|c|}
\hline \multicolumn{3}{|l|}{ Bacteria } \\
\hline $\begin{array}{l}\text { Streptomyces } \mathrm{sp} . \\
\text { Pseudonocardia } \mathrm{sp} . \\
\text { Bacillus cereus } \\
\text { Acinetobacter lwoffii }\end{array}$ & $\begin{array}{l}\text { Enzymatic degradation of collagen, } \\
\text { structural damage. }\end{array}$ & $\begin{array}{l}\text { Karbowska-Berent and } \\
\text { Strzelczyk (2000), Piñar } \\
\text { et al. (2015c), Lech (2016) }\end{array}$ \\
\hline $\begin{array}{l}\text { Nocardiopsis salina } \\
\text { Saccharopolyspora } \mathrm{sp} .\end{array}$ & $\begin{array}{l}\text { Enzymatic degradation of collagen, } \\
\text { structural damage } \\
\text { Production of stains (red, purple). }\end{array}$ & Piñar et al. $(2015 b, c)$ \\
\hline $\begin{array}{l}\text { Halomonas sp. } \\
\text { Halobacillus } \mathrm{sp} . \\
\text { Halobacterium } \mathrm{sp} .\end{array}$ & $\begin{array}{l}\text { Production of stains (red, purple), } \\
\text { in presence of hygroscopic salts } \\
\text { (sulphates, chlorides) used in } \\
\text { manufacturing of parchment, initial } \\
\text { attack (halophilic species). }\end{array}$ & $\begin{array}{l}\text { Piñar et al. (2015c), Migliore } \\
\text { et al. (2019) }\end{array}$ \\
\hline $\begin{array}{l}\text { Bacillus } \mathrm{sp} . \text { (B. cereus) } \\
\text { Acinetobacter } \mathrm{sp} . \\
\text { (A. lwoffii) } \\
\text { Stenotrophomonas } \mathrm{sp} . \\
\text { (S. maltophilia) }\end{array}$ & $\begin{array}{l}\text { Enzymatic degradation of collagen, } \\
\text { structural damage. }\end{array}$ & Piñar et al. (2015c) \\
\hline $\begin{array}{l}\text { Arthrobacter } \mathrm{sp} . \\
\text { Methylobacter } \mathrm{sp} .\end{array}$ & $\begin{array}{l}\text { Production of stains red-pigmented } \\
\text { (carotenoids production). }\end{array}$ & $\begin{array}{l}\text { Piñar et al. (2015c), Lech } \\
\text { (2016) }\end{array}$ \\
\hline
\end{tabular}


contaminants, even those that do not grow in culture, is growing longer and more accurate with the advent of new investigative techniques based on the extraction and sequencing of DNA.

The microorganisms that are identified in the air and on materials in libraries, archives and book repositories using massive sequencing methods include those typically found growing in indoor environments as well as those introduced from outdoors (Liao et al. 2004; Borrego et al. 2012; Nunes et al. 2013). Fungi that are obviously "outdoor" additions to the indoor environment often include ecto- and arbuscular-mycorrhizal genera that are obligate associates of host plants. The presence of mammalian mycobionts such as Candida albicans, Malassezia spp. and bacterial species belonging to the group Propionibacterium/Cutibacterium shows that humans contribute directly to the microbiome of indoor dust. Other bacteria of cutaneous origin, belonging to the genera Corynebacterium and Staphylococcus (Ramsey et al. 2016), have often been detected on archival documents in the past (Puškárová et al. 2016; Kraková et al. 2012, 2018).

The main limiting factor that permits fungal development on paper and parchment is water. Spore germination only occurs when some water is available. From an ecological standpoint, it is possible to imagine at least two different scenarios in which a microbiological attack on books and documents is possible (Figs. 4.2, 4.3, 4.4): (1) a sudden abundance of water, such as in the case of flooding or pipe rupture and (2) a situation in which a microclimate is established that encourages the development of particular organisms possessing the essential characteristics which make them eminently suited to occupying a particular ecological niche ( $\mathrm{Gu}$ et al. 2013; Sato et al. 2014). These are very different situations that can lead to conflicting biodeterioration mechanisms as well as non-comparable effects on materials.

The microbial community that inhabits the indoor environment depends on the level of abiotic stress (e.g. low water availability, poor resources). The fungal and bacterial species that take advantage of a sudden availability of free water in a library are usually r-selected organisms capable of arriving, establishing themselves and persisting until reproduction and dissemination have been accomplished (Boddy and Hiscox 2016). Community change occurs when the initial colonizers are substituted by organisms that are either better able to tolerate conditions within the resource, or capable of using the resource modified by the initial colonizers and their residue. Competition for space and food may involve specialized species-specific interactions such as mycoparasitism, or be more generalized, but in any case will involve metabolic changes, reactive oxygen species production, acidic compounds and antibiotics release into the immediate environment, with the result that community development on materials is not a predictable and ordered sequence, but instead a complex, ever-changing and rather haphazard process (Boddy and Hiscox 2016).

The fast-growing fungal species that develop on paper and other organic materials stored in libraries and archives can generate strong odours (Pinzari and Montanari 2011; Micheluz et al. 2016), coloured stains (Melo et al. 2019) and toxic compounds (Micheluz et al. 2016). Substrate composition and the availability of degradable carbon sources such as sugars and starch or mineral nutrients like nitrogen, phosphorus and potassium can be determining factors in the growth of the 

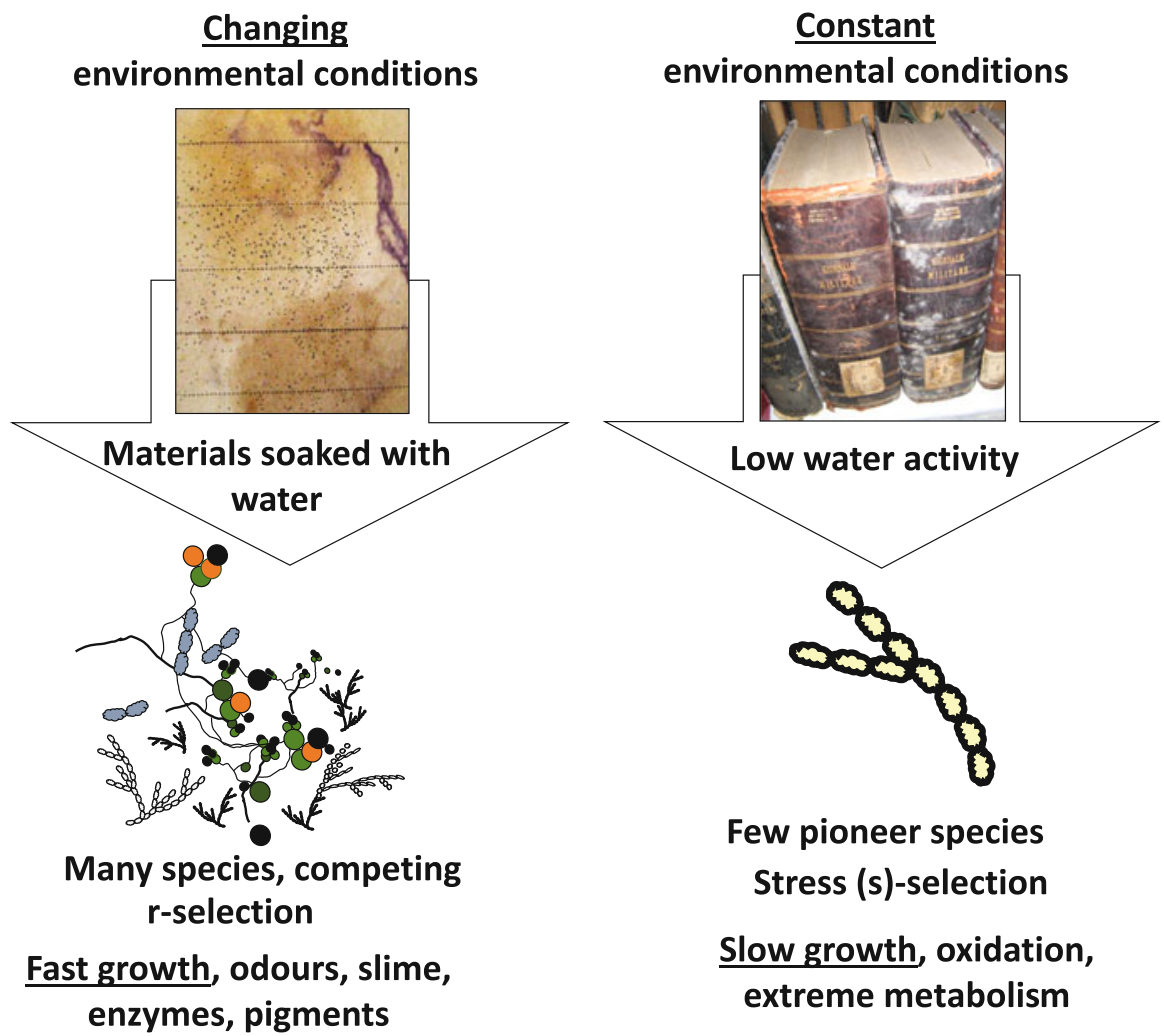

\section{Few pioneer species}

Stress (s)-selection

\section{Slow growth, oxidation, extreme metabolism}

Fig. 4.4 Diagram summarizing the two broad categories in which it is possible to separate the principal library and archival documents biodeterioration mechanisms. The main distinction is based on the availability of free water. A sudden availability of water is advantageous for organisms that are able to grow rapidly, and which have evolved to resist environments that change continuously, such as those that survive as airborne spores. They are species that produce many spores, compete with each other, and exploit the substrate in an efficient way (i.e. by secreting powerful enzymes). The opposite category consists of species of microorganisms that have evolved to colonize limiting environments, in the absence of competitors but under constant conditions. These organisms are often pioneering species that grow rather slowly and exhibit a metabolism adapted to extreme conditions, that is with little water availability or high osmotic pressure (i.e. when high salts concentrations are present in the substrate)

mycelia and the production of fruiting bodies and spores by the fungi. The competition between microbial species for water, nutrients and space in indoor environments also accounts for the time needed by the fungus to germinate or grow when a favourable situation arises. Library micro-environments characterized by transient high humidity (such as air conditioning units, or walls that absorb humidity from heavy downpours) typically support the growth of fungi capable of re-starting their growth from the dry hyphal tips within a few hours following a re-wetting event; this is the case with Alternaria, Aureobasidium, Cladosporium, Phoma, and Ulocladium genera (Nielsen 2002, 2003). The development of the microorganisms that require 
high water activity typically takes longer, subsequent to a sudden wetting event. The growth of mycelium and production of spores directly in the materials after they have been soaked with water usually takes a couple of days and depends on the ambient temperature. In fact, after flooding, librarians and conservators know that water-impregnated materials must be refrigerated or dried hastily so as to arrest the development of fungi and bacteria.

By contrast with what has been described so far for organisms capable of taking advantage of randomly and suddenly favourable situations, it is also possible to encounter very different species living on book materials and in libraries. The microorganisms that establish themselves on materials when environmental conditions are extreme, but constant, are typically slow-growing species that are particularly resistant to stress (Fig. 4.4). These species are defined as "stress-tolerant" or "s-selected"; they are specialized in occupying specific niches and their particular advantage is the ability to survive and disperse in a very hostile environment. The "s-selected" fungal species that inhabit indoor environments can tolerate desiccation and grow in restrictive conditions (Boddy 2000).

\section{Random Events, Common Denominators, Model Mechanisms}

\subsection{Actors and Mechanisms}

The wide diffusion and frequency of some bacterial and fungal species as confirmed spoilers of archival and library materials have only recently begun to emerge thanks to an increase in the number of diagnostic investigations based on massive DNA sequencing techniques that extend beyond the limits of culture-dependent investigations. Over the last ten years or so, various articles have been published which have clarified some biodeterioration mechanisms and the ecology of particular species responsible for phenomena that, although widespread, were previously unknown (Montanari et al. 2012; Piñar et al. 2015a, b, c; Pinzari et al. 2012a, 2018, Melo et al. 2019; Migliore et al. 2019).

Even if it is impossible to imagine perfectly repeatable patterns of material biodeterioration caused by the different groups of microorganisms, we can describe recurrent situations where phenomena can be parameterized, so as to model and forecast the risks posed by one or another biodeterioration mechanism, based on the presence of specific environmental conditions or the assemblage of microbial species (Fig. 4.4).

The initial creation of two broad categories, as mentioned above, is based on the availability of free water. If there is plenty of water available, such as in a sudden and unexpected event (a flood, for example), the microorganisms that attack the paper or the parchment grow rapidly, produce pigmented stains and strong odours, abundant exopolymeric material, and exhibit significant enzymatic activity that results in the 


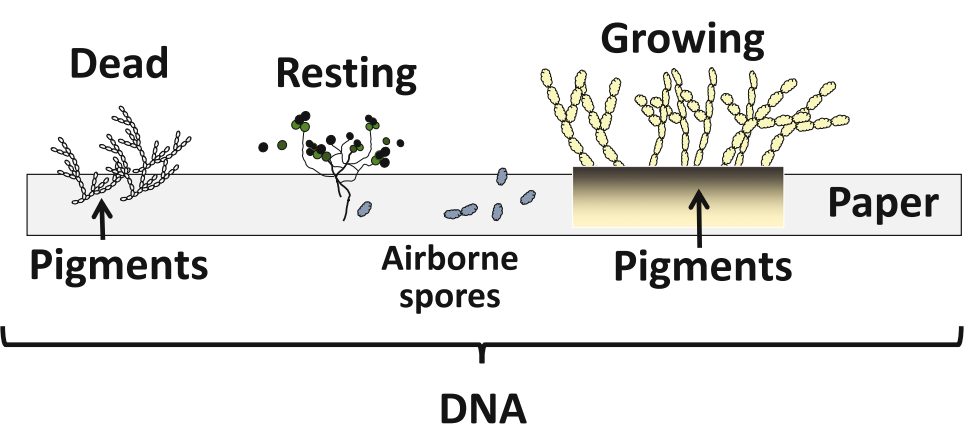

Fig. 4.5 Diagram showing the different conditions in which microorganisms can be found in a material such as paper. Some can be active and grow, and produce pigments, whereas others can be viable but dormant; others still can be dead remains. Finally, it is possible to have many microorganisms represented by individual spores, deposited from the air, viable or otherwise. All the organisms present in the various physiological states are detectable using massive DNA sequencing analysis. In order to be able to distinguish among a long list of candidates that are responsible for damage, it is necessary to add to the genetic analysis further diagnostic techniques, capable of distinguishing the viable species from the dead ones or to describe a causative mechanism behind the damage

destruction of cellulose fibres in the case of paper and of collagen in the case of parchment (Figs. 4.2, 4.3, 4.4). In this biodeterioration scenario the species, both bacterial and fungal, can be numerous and multifarious. They are often the same as those found in dust, although sometimes unusual saprophytes are identified that are transported by chance on the materials and suddenly placed in a situation where they can germinate and grow at the expense of large quantities of organic matter (Fig. 4.5) (Pinzari and Montanari 2008). During the slow drying of the sodden materials a succession of organisms occurs that gradually take over from each other by taking advantage of the partially degraded matter and the remains of the first settlers. This represents a natural succession mechanism that can produce very similar results, albeit depending (in each instance) on a different assortment of species, all of which are capable of rapid growth, in addition to being endowed with enzymes and metabolites diffusible in abundant water and different competition mechanisms (e.g. the production of antimicrobial compounds or volatile products with allopathic functions) (Pinzari et al. 2004; Canhoto et al. 2004; Sawoszczuk et al. 2015; Micheluz et al. 2015, 2016).

Cellulolytic and proteolytic enzymes cause structural damage by means of a precisely targeted attack of the covalent chemical bonds of macromolecules (i.e. cellulose and collagen), whilst organic acids promote oxidation mechanisms and chelate microelements, such as calcium and iron (Fig. 4.1). Metals and salts can precipitate as secondary compounds between the fibres, thereby increasing spatial heterogeneity, which in turn facilitates the coexistence of multiple species of spoiling microorganisms, each linked to a particular microenvironment and capable of causing a different type of damage to the material in question (Pinzari 2018). 
Table 4.2 lists some of the mechanisms involved in paper and parchment biodeterioration caused by bacteria and fungi. Aspergillus and Penicillium fungal species are among those most frequently associated with the production of organic acids and other metabolites, which can react with various components of paper (Fig. 4.2). In fact, not only cellulose can be affected by oxidative reactions and enzymatic degradation. The presence of starch, gelatin, rosin and other glues, or that of salts and mineral compounds can exert an influence on fungal metabolism and determine, for example, the kind of stains produced (Fig. 4.2). The fungal pigments that affect paper have been associated to polyketide quinones, carotenoids and other compounds whose synthesis or colour can depend on the availability of nitrogen, the prevailing $\mathrm{pH}$ and the presence of other limiting nutrients and enzyme cofactors such as metals and cations (i.e. Fe, K, Ca, Mg, Mn) (Melo et al. 2019). However, in order for fungi to be able to produce abundant enzymes and synthesize complex metabolites, there must be no limiting factors, and therefore water must be available together with the organic matter.

When free water is scarce, the microbiological attack on the materials takes place differently (Figs. 4.3, 4.4). It is slower, and there are only a few or single extremophile species that can germinate and grow. In such situations, generally linked to specific microenvironmental conditions, the secretion of enzymes, organic acids and pigments also occurs, albeit to a lesser extent and with limited diffusion, and often producing different effects depending on the species concerned. The appearance of damage on the material, alterations, and also identifying the presence of a biodeterioration phenomenon in progress in such cases may not be immediate, but instead occur over a long period of time. While in the case of a flood the development of microorganisms is a virtual inevitability, the outcome of other crises is far less predictable, owing to local phenomena, micro-environments or extremophile species that involve mechanisms that are more complex and difficult to predict.

An example of slow-forming damage that gradually makes itself apparent is foxing (Choi 2007; Nunes et al. 2015; Modica et al. 2019). The formation of foxing stains on paper and other materials can be caused by fungi as a result of limited water availability. Absolute tonophilic fungi germinate on paper in the presence of very low water availability $\left(a_{\mathrm{w}}<0.80\right)$ and release cello-oligosaccharides, aminobutyric acid and amino acids. These compounds condensate in a spontaneous chemical reaction (Maillard condensation) to form brown-coloured compounds known as "melanoidins" (Arai 1987, 2000; Arai et al. 1990), which in many cases are responsible for foxing stains.

Pinzari (2018) described three types of biodeterioration mechanisms with increasing levels of complexity: (1) the damage is caused by the enzymatic activity of microorganisms and is focused on the main chemical component of the material, as in the case of cellulolytic fungi that attack paper soaked with water; (2) the damage is caused by the presence of peculiar conditions that trigger species with very particular requirements, e.g. extremophilic species that grow at the presence of salts; (3) the damage is the result of several related events such as the succession of species that feed on each other remains, with a primary colonizer which is often able to drastically modify the initial conditions of the material (as in mechanisms 1 and 
2). Understanding what causes damage, which species are involved, the resulting metabolites and the chemical changes undergone by the materials are not a mere speculative exercise. The microorganisms' ecology, their growth requirements and the overall biodeterioration mechanism can all have a very significant effect on the outcomes of the conservation treatments. Here we describe three examples where the biodeterioration mechanisms have been examined in detail (Figs. 4.3, 4.6): (1) a rare fungal species, linked to the droppings of mites and the presence of salts, which attacked the preparatory layer of an illuminated parchment and caused its detachment; (2) a fungus, a solitary colonizer with extremophile characteristics, which found its ideal niche in libraries; (3) a complex turnover of species that recurs in ancient parchments all over the world, consistently causing the same type of damage (Figs $4.3 \mathrm{a}, \mathrm{b}$ ).

\subsection{A Rare Fungal Species}

The halophilic fungus Diploöspora rosea (Tanney et al. 2015) was observed growing copiously on a twentieth-century illuminated parchment (Fig. 4.6). The framed parchment leaf was on display in a museum, hung on a wall affected by rising damp. The fungus was documented on the thick preparative layer of gypsum and calcium carbonate, and was seen to be capable of developing on the green pigments used for the illumination. The pigments were prepared using chromium, iron and arsenic salts. D. rosea grew not only in the presence of toxic metals but also showed the ability to produce fruiting structures on very low water activity media, including malt extract agar amended with $60 \%$ sucrose. Despite the extreme xerophilic nature of this fungus, its structures caused the detachment of large parts of the artwork's preparative layer and the overlying illumination. D. rosea is an onygenalean fungus, of uncertain taxonomic position, basal or sister to the Gymnoascaceae that seems to occur in archival and domestic environments subject to periodic wetting. This fungus was previously identified in 1913, on damp cardboard covered with several fungi. The dominant fungus was unknown and was described as the type species of the new hyphomycete genus Diplö̈spora. In the 100 years following its first collection, it was reported exclusively in association with illuminated parchments and in indoor settled dust in Micronesia. In the biodeteriorated parchment samples, D. rosea grew with other unidentified fungi and house mite exuvia and faeces pellets. Mite faeces were also observed on the holotype (i.e. the 1913 cardboard). This hints at an insect/mite-mediated dispersal mechanism for this fungus. The high salt and nitrogen concentrations that characterize mite droppings may represent a selective niche for osmophilic fungal species. The vast geographical distance between specimens suggested that $D$. rosea may have a broad distribution. Its apparent rarity may reflect its xerophilic nature and slow growth rate rather than its actual prevalence. However, its rarity in indoor settled dust samples was confirmed by the detection of only two similar sequences using pyrosequencing. This case study shows how some fungal and bacterial species, rarely found in nature, can 

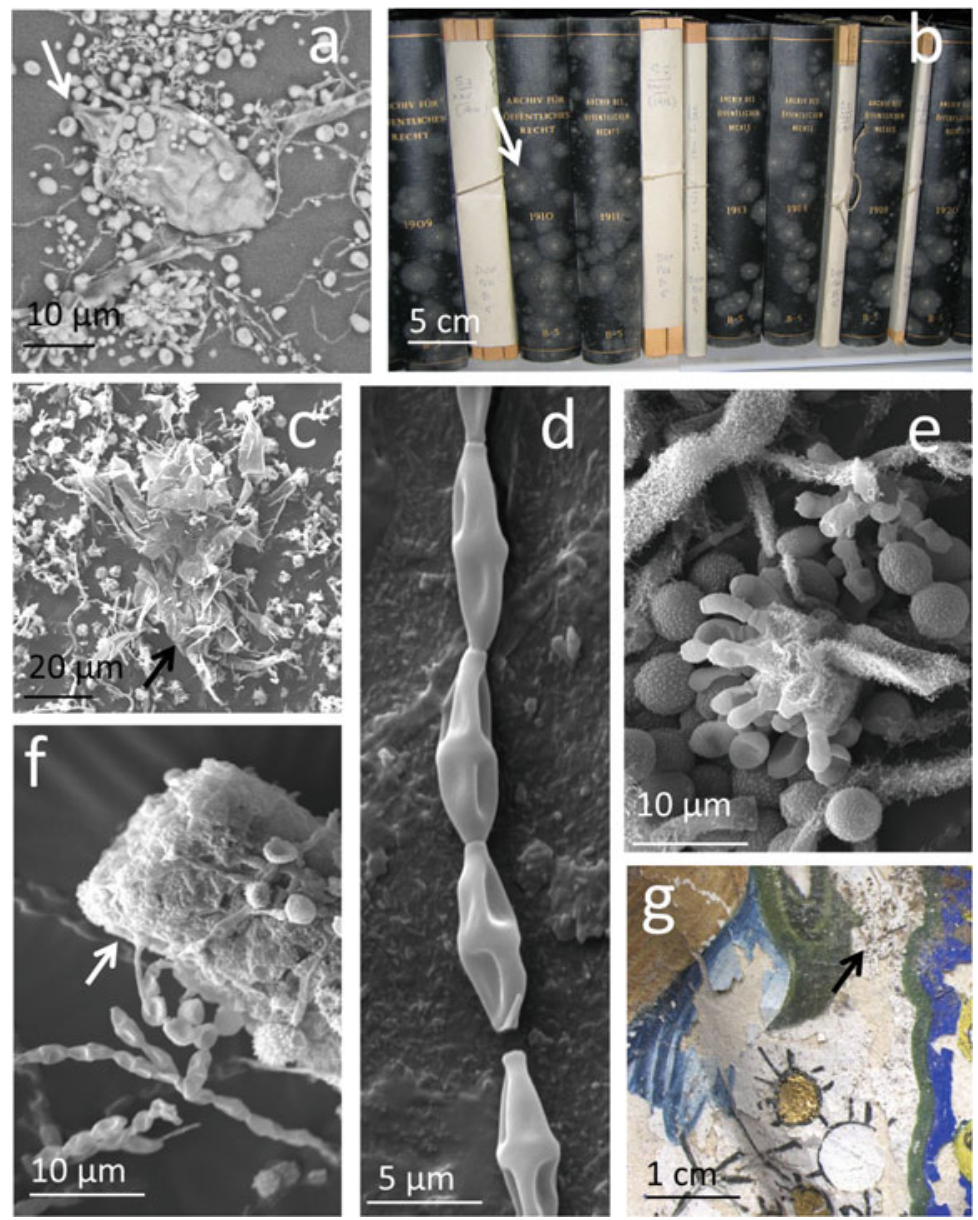

Fig. 4.6 Two examples of fungi considered rare and characterized by a singular ecology, which have been shown to be capable of shifting with ease from extreme natural environments to man-made niches: Eurotium halophilicum and Diploöspora rosea. Both are osmophilic species, growing only on low water activity media. They are both associated with mites for their dispersion; (a) SEM image (variable pressure, non-coated sample), mycelium and spores of E. halophilicum infiltrating the remains of a mite (arrow = head of the mite); (b) E. halophilicum as a monospecific infection, forming white colonies on the spines of volumes in a library; (c) D.rosea and other fungal species close to the exuvial remains of a mite (arrow = head of the mite); (d) D. rosea chains of conidia (high vacuum SEM image on a gold-coated sample); (e) mycelium, head of conidiophore and spores of $E$. halophilicum (high vacuum SEM image on a gold-coated sample); (f) the dung of a mite containing spores of an Aspergillus species and infiltrated by the mycelium of $D$. rosea (high vacuum SEM image on a gold-coated sample); (g) the illuminated parchment upon which $D$. rosea developed. The gypsum-based layer and the pigments deposited on the parchment proved to be a perfect niche for this fungus 
find in the niches created by man their ideal environment where they can develop and proliferate, sometimes without competition. In the case of the D. rosea, however, several factors seem to have played a role, such as the possible repeated wetting events suffered by the material, the presence of mites and their droppings, the mineral nature of the substrate that allowed the fungus to thrive, despite being an osmophilic species, probably at the expense of the glues used to consolidate the preparatory layer, subsequently causing the detachment of the illuminations.

\subsection{A Solitary Colonizer}

Occasionally, some fungi considered rare and of singular ecology, not only occupy a niche of the anthropic environment, but also find effective means of diffusion, and therefore become particularly invasive. They are often intrusive species, capable of shifting with alarming ease from extreme natural environments to man-made niches. A good example of this behaviour is provided by the spread of the fungus Eurotium halophilicum in Italian libraries and archives (Pinzari and Montanari 2011; Montanari et al. 2012) (Fig. 4.6). Eurotium halophilicum is a xerophilic fungus, with high tolerance to water stress; it was first isolated from dry food and indoor dust in association with other xerophilic fungal species and dust mites (Montanari et al. 2012; Micheluz et al. 2015) (Fig. 4.6). Since the first reports of it as a book contaminant, it has been identified in dozens of libraries and archives in Italy as the main, if not the sole fungus flourishing on books and archival materials (Pinzari and Montanari 2011; Montanari et al. 2012; Micheluz et al. 2015; Polo et al. 2017). It has also been linked to the appearance of foxing-like stains on materials (Piñar et al. 2015c; Sclocchi et al. 2016). The minimum water activity value observed for its successful germination and growth is 0.675 (Christensen et al. 1959). It has repeatedly been found in association with the covers of books and other surfaces within museums, libraries and archives, even when the overall environmental conditions are in line with those recommended for the conservation of the materials (i.e. relative humidity values ranging from 50 to $60 \%$, and a temperature ranging from 20 to $22^{\circ} \mathrm{C}$ ). The niches preferred by this fungus are characterized by infrequent ventilation and water condensation events after a drop in temperature or night/day thermic cycles. The inadequacy of sampling procedures and the very slow growth of the fungus on most media probably account for previous underestimations. Another xerophilic fungus, Aspergillus penicillioides, has often been isolated from books in association with $E$. halophilicum, probably due to its similar ecology. Other fungi have frequently been isolated from E. halophilicum mycelium: Aspergillus creber, A. protuberus, Penicillium chrysogenum and P. brevicompactum (Micheluz et al. 2015). These species grow on the dead mycelium of E. halophilicum. It has been observed that their presence is associated with historic infections of the fungus. As long as the mycelium is alive, the fungus remains the only organism on materials, and therefore represents the primary colonizer. Once established and mature, its mycelium serves as a substrate for other xerophilic organisms. Dead structures of the 
fungus E. halophilicum have also been found in foxing spots on paper and other materials. Metal oxalates have often been documented in association with fungal hyphae (i.e. calcium oxalates) (Pinzari et al. 2010). These findings are consistent with the hypothesis that absolute tonophilic fungi germinate on paper, releasing organic acids, oligosaccharides and amino acids. The damage that this fungal species causes to materials consists of pale brown to dull grey stains and other forms of decolouration (Figs. 4.3c, 4.6). When decomposition occurs, it is limited to small areas and consists of a sort of superficial erosion. This fungus also produces volatile organic compounds (Micheluz et al. 2016) and represents a potential hazard for workers who manage infected materials. GC-MS analysis showed that E. halophilicum produces at least 20 different volatile compounds, with acetone and 2-butanone being the main products. A total of eight secondary metabolites were detected through LC/MS-MS, e.g. deoxybrevianamid E, neoechinulin A and tryprostatin B (Micheluz et al. 2015).

\subsection{A Complex Turnover}

In the two examples of the microbiological attack described above, the agents responsible for the colonization of the material and the main spoiling effects it results in have been identified. The other organisms associated with them have been attributed to secondary phases that only played a marginal role in the mechanism. The situation in which all or most of the organisms present in the alterations play a role and are part of a complex mechanism whose phases are difficult to reconstruct is quite different. An example of a complex mechanism is described in the works of Gallo and Strzelczyk (1971), Petushkova and Koestler (1996), Karbowska-Berent and Strzelczyk (2000), Piñar et al. (2015a, b, c), Migliore et al. $(2017,2019)$ (to cite only the main ones), where more than once and by means of different and progressively more sophisticated methods the cause of the formation of purple stains on parchment leaves was sought (Fig. 4.3a, b).

The parchment alteration that has long intrigued many experts consists of red or purple nucleated maculae with peripheral halos, isolate or coalescent, often associated with perforations and a loss of material which is more severe on the "flesh side" of a leaf. Karbowska-Berent and Strzelczyk (2000) isolated species of Streptomyces from the purple stains marring several documents of different ages and origins. They found that many of the strains had proteolytic enzymes that are capable of destroying collagen through their hydrolytic activity and were alkaliphiles, hence able to develop on skins prepared with lime and chalk (Figs. 4.1b, 4.3a, b). The isolated bacteria, however, did not reproduce the purple stains when inoculated on modern parchment.

Piñar et al. (2015a) analysed five documents with different histories and origins, all marred by purple spots. Both scanning electron microscopy and molecular analysis, based on culture-independent techniques (total DNA extraction, cloning and sequencing of bacterial 16S and fungal ITS rRNA genes), detected the presence 
of bacteria and fungi in the damaged areas. Halophilic, proteolytic bacterial species were found in all the documents. Moreover, as common microbial denominators, members of the Actinobacteria, mainly Saccharopolyspora spp. and species of the fungal genus Aspergillus, were detected in all investigated cases. Piñar et al. (2015a) proposed that a relationship exists between the phenomenon of purple spots appearing on ancient parchments and that of so-called red heat, known to affect some leather and animal skin products manufactured with marine salt and associated with the presence in the salt of extremophilic living bacteria.

Migliore et al. (2017) used 16S rRNA gene analysis in conjunction with 454-pyrosequencing to study the purple spots on a parchment roll dated to 1244 A.D. They hypothesized a two-phase model mechanism of parchment colonization, where halophilic Archaea colonize parchment as pioneers, followed by Gammaproteobacteria, and fungi as the last colonizers. In a second study (Migliore et al. 2019), the microbiomes of three parchment manuscripts affected by purple spots were analysed by means of next-generation sequencing (Illumina platform). In this instance, the authors attributed to Halobacterium salinarum the role of common denominator in the purple stains, along with that of the primary, triggering cause of the phenomenon. They identified as haloarchaeal bacterioruberin and bacteriorhodopsin the pigment within the purple spots using RAMAN spectroscopy. Migliore et al. (2019) proposed a further multi-phase microbial succession model leading to progressive degradation of the parchment's collagen. In the suggested mechanism, the first phase "pioneer" colonizers are the halophilic and halotolerant microorganisms inhabiting the brines used to cure the skins. The second phase "late" colonizers consist of other bacteria and fungi that can vary among different environments and according to the life history of each document. The halophilic and halotolerant microbes from the marine salt enter the hides during the manufacturing process, forming the core of the purple spot damage (Perini et al. 2019). They develop inside the parchment and release proteolytic and lipolytic enzymes which attack and degrade the collagen's fibres. The formation of the nucleated purple stains was explained as the result of the lysis of halobacterial cells, with the subsequent release of bacteriorhodopsin and nutrients that can trigger colonization by other halotolerant organisms of the proteobacterial taxa (mainly Gammaproteobacteria) and Firmicutes. In the model formulated by Migliore et al. (2019), both actinobacteria and fungi are involved in the damage caused to skins because of their ability to attack not only the collagen but other compounds too, although they only participate in the last phases of the succession. Confirmation of a late role played by fungi in the colonization of parchment in areas already affected by purple spots came from different studies. Pinzari et al. (2012a) quantified both the adenosine triphosphate (ATP) and the fungal $\beta(1-4)-\mathrm{N}$-acetyl-D-glucosaminidase activity in damaged and undamaged samples, concluding that the viable fungal mycelium was present, albeit not strictly associated with the purple stains. Additionally, Piñar et al. (2015b) quantified the $\beta$-actin gene through real-time polymerase chain reaction analyses (qPCR) in parchment samples affected by purple spots (taken from the Archimedes Palimpsest). They identified a greater abundance of fungi on degraded areas in comparison to healthy ones. A broader statistic on the communities of 
microorganisms associated with purple spots in the future will make it possible to draw clearer conclusions and fill the current gaps in the "puzzle", such as a potential specific role of the actinobacterium Saccharopolyspora, found on practically all the documents affected by purple spots (Piñar et al. 2015a, b; Teasdale et al. 2017, Migliore et al. 2017).

\section{Perspectives}

Systems biology is the study of the interactions and behaviour between the components of biological systems, and how these interactions give rise to the function of that system (for example, the enzymes and metabolites in a metabolic pathway). Systems biology also offers a useful way of thinking and of conducting research, with a more in-depth focus on complex interactions within biological systems, using a holistic approach, instead of reductionism. The future of research in the field of biodeterioration of cultural heritage, and in particular of paper and parchment documents lies, in fact, in a systemic vision of processes, and in a merging of current knowledge with all the multiple and multidisciplinary clues that will be obtained through the investigations conducted during new case studies. One of the aims of systems biology, namely to model and discover emergent properties, when applied to the study of paper and parchment biodeterioration, will facilitate reaching a better understanding of the mechanisms involved.

In the not too distant future, system biology tools will be developed to uncover the functions of the metabolites present in materials and to trace them back to the organisms that produced them. It should also be possible to predict the behaviour of communities when many environmental variables change in concert, as well as to understand the role played by individual taxa in complex communities.

The application of innovative molecular biology techniques, correlative microscopy and chemical mass spectroscopy methods has already permitted some in-depth analyses of paper and parchment biodeterioration mechanisms, as reported in some recent studies (Kraková et al. 2012, 2018; Piñar et al. 2015a, b, c; Teasdale et al. 2017; Sawoszczuk et al. 2017; Sanmartín et al. 2018; Cicero et al. 2018, Szulc et al. 2018, Mazzoli et al. 2018; Melo et al. 2019, Migliore et al. 2019; Marvasi et al. 2019). In recent times, all the interest focused on the study of biodeterioration phenomena has been directed towards a group of technologies known as "omics", which have revolutionized the approach to environmental studies. These include metagenomics, transcriptomics, metabolomics and proteomics; they are used to study total genomes and transcripts, to identify enzymes and proteins in very small samples, and to recognize the metabolites and the metabolic pathways active in materials. It is undeniable that omics tools have ushered in a new era in biological and chemical studies and have rapidly become the basic tools for all the environmental microbiology studies. They have proved to be particularly useful where there are interactions between microbiological consortia or between individual microorganisms or microorganisms and the environment. Although developed over the last 
ten years or so, the application of omics to the study of cultural heritage and, in particular, to archival documents and materials is only now beginning to gain ground, as are the concepts of systemic biology. Indeed, very recently Illumina MiSeq was used for massive DNA sequencing to analyse the microbiological biodiversity in historical samples of paper and parchment. The technique was applied in order to better understand phenomena which up till now have remained controversial. In fact, it was applied for the purpose of comparing brown foxing spots on paper and purple spots on parchment (Szulc et al. 2018, Migliore et al. 2019). The study identified the contribution of new microorganisms (Phoma, Cladonia moulds and Gluconobacter, Ralstonia bacteria) to the foxing phenomena observed on 19th-century paper (Szulc et al. 2018); it also helped to establish the mechanism underlying the microbial succession that occurs in purple stains on parchment, with haloarchaea establishing initially, followed by halotolerant bacteria, then actinobacteria, and finally fungi arriving at the end of the deterioration process (Migliore et al. 2019). In addition to massive DNA sequencing techniques, metabolomic techniques have been shown to provide useful elements for understanding the mechanisms underlying the biodeterioration of materials (Fig. 4.5). Metabolomics encompasses a comprehensive qualitative and quantitative analysis of small molecule substances with various properties that contribute to the metabolic pathways in the system under study. Metabolomics and proteomics provide information on biological mechanisms and potential biomarkers in samples. Recently, metabolomic analysis based on the AuNPET SALDI-ToF-MS method was applied in the study of foxing stains marring some 19th-century papers. This technique enabled the authors (Szulc et al. 2018) to demonstrate the occurrence in the stained areas of several metabolic pathways, including sugar degradation, amino acid and protein metabolism, ubiquinone and other terpenoid-quinone biosynthesis, 2-methyl-6-phytylquinol and delta-, gamma-, beta-tocopherols (responsible for the yellowish-brown colour of foxing spots) and 3-hydroxy-L-kynurenine (a fluorescent, yellow compound). These pigments can all contribute to the mechanism underlying the appearance of foxing caused by microorganisms (Szulc et al. 2018).

Notwithstanding the considerable body of knowledge with respect to the metabolic processes occurring in organisms, the number of identified metabolites in databases, particularly for microorganisms involved in cultural heritage deterioration, remains limited. Having a complete database that also includes the metabolism of taxa of non-biomedical or food interest is a goal yearned for by all microbiologists working in the field of environmental metabolomics (Marvasi et al. 2019). Similarly, public databases that facilitate the alignment of diagnostic sequences for the identification of fungi and bacteria are often lacking for taxa whose species are poorly studied, of little interest, and troublesome to cultivate in vitro, and hence poorly represented in living culture collections. This is a common situation for microorganisms that attack cultural heritage. Molecular ecology studies are very effective in capturing biodiversity, but the fungal and bacterial isolates conserved as living collections allow for studies of growth, morphology, secondary metabolism, genomics and other traits (Paiva de Carvalho et al. 2016). Without the existence of a 
living culture that makes it possible to couple morphological observations and DNA extraction, many molecular sequences are of little use since they often result in poor matches with sequences stored in public databases. This state of affairs underscores the importance of actively collecting and accessioning sequences of described species that are currently unrepresented in sequence databases (new or unsequenced species). Populating databases, such as GenBank, with verified sequences obtained from organisms isolated in cultural heritage biodeterioration studies will improve future amplicon-based metagenomics studies. In addition to meagre databases, the environmental sector and especially the cultural heritage sector suffer from a paucity of computational biology tools that would make it possible to combine genetic and chemical data, or informatics tools that would be of help in modelling biodeterioration mechanisms, so as to be able to predict the processes before they happen (Sterflinger et al. 2018).

If we had adequate and specifically earmarked funds for research in the field of biodeterioration of cultural heritage, we could envisage the development, in the not too distant future, of bioinformatics tools capable of utilizing the masses of data already available and those that are rapidly being generated, so as to enable us to identify unique chemical or genetic markers associated with the deterioration of materials (e.g. early diagnostic systems that predict harmful mechanisms based on a few metabolomic or genomic clues).

The quantity of data obtained during omics analyses is enormous: a single, relatively simple experiment aimed at analysing a microbial metabolome generates tens of thousands of spectra. These data, as well as those obtained from studies of metagenomics and transcriptomics, which can be directly associated with the biodeterioration mechanisms of materials and chemical data on the materials themselves, should by rights already be collected within a single public database. This would permit the development of appropriate tools for bioinformatics and networks analysis, and therefore promote and stimulate further studies on the mechanisms and preventative methods, as well as early diagnosis of cultural heritage biodeterioration.

Acknowledgements We would like to thank Mark Livesey for his helpful suggestions during the preparation of the English text, and the anonymous reviewer for the meaningful comments.

\section{References}

Arai H (1987) Microbiological studies on the conservation of paper and related cultural properties. Part 5. Physiological and morphological characteristics of fungi isolated from foxing, formation mechanisms and countermeasures. Sci Conserv 26:43-52

Arai H (2000) Foxing caused by fungi: twenty-five years of study. Int Biodeter Biodegr 46:181-188. https://doi.org/10.1016/S0964-8305(00)00063-9

Arai H, Matsumura N, Murakita H (1990) Microbiological studies on the conservation of paper and related cultural properties, part 9, induction of artificial foxing. Hozon Kagaku 29:25-34. (in Japanese) 
Ayu DC, Teja TP (2016) Occurrence of fungi on deteriorated old dluwang manuscripts from Indonesia. Int Biodeter Biodegrad 114:94-103. https://doi.org/10.1016/j.ibiod.2016.05.025

Blyskal B, Lenart-Borod A, Borod P (2017) Approaches to taxonomic studies of actinomycetes isolated from historic and contemporary materials. J Pure Appl Microbiol 11:637-648

Boddy L (2000) Interspecific combative interactions between wood decaying basidiomycetes. FEMS Microbiol Ecol 31:185-194

Boddy L, Hiscox J (2016) Fungal ecology: principles and mechanisms of colonization and competition by saprotrophic fungi. Microbiol Spectrum 4: FUNK-0019-2016

Borrego S, Lavin P, Perdomo I, Gómez de Saravia S, Guiamet P (2012) Determination of indoor air quality in archives and biodeterioration of the documentary heritage. ISRN Microbiol 2012:680598

Brunner I, Fischer M, Rüthi J, Stierli B, Frey B (2018) Ability of fungi isolated from plastic debris floating in the shoreline of a lake to degrade plastics. PLoS ONE 13:e0202047. https://doi.org/ 10.1371/journal.pone.0202047

Canhoto O, Pinzari F, Fanelli C, Magan N (2004) Application of electronic nose technology for the detection of fungal contamination in library paper. Int Biodeter Biodegr 54:303-309. https://doi. org/10.1016/j.ibiod.2004.04.001

Choi S (2007) Foxing on paper: a literature review. J Am Inst Conserv 46:137-152. https://doi.org/ $10.1179 / 019713607806112378$

Christensen C, Papavizas GC, Benjamin CR (1959) A new halophilic species of Eurotium. Mycologia 51:636-640

Cicero C, Pinzari F, Mercuri F (2018) 18th Century knowledge on microbial attacks on parchment: analytical and historical evidence. Int Biodeter Biodegr 134:76-82. https://doi.org/10.1016/j. ibiod.2018.08.007

Cordero RJB, Casadevall A (2017) Functions of fungal melanin beyond virulence. Fungal Biol Rev 31:99-112

Coronado-Ruiz C, Avendaño R, Escudero-Leyva E, Conejo-Barboza G, Chaverri P, Chavarría M (2018) Two new cellulolytic fungal species isolated from a 19th-century art collection. Sci Rep 8:1-9. https://doi.org/10.1038/s41598-018-24934-7

Corte AM, Ferroni A, Salvo VS (2003) Isolation of fungal species from test samples and maps damaged by foxing, and correlation between these species and the environment. Int Biodeterior Biodegradation 51:167-173. https://doi.org/10.1016/S0964-8305(02)00137-3

De Paolis MR, Lippi D (2008) Use of metabolic and molecular methods for the identification of a Bacillus strain isolated from paper affected by foxing. Microbiol Res 163:121-131. https://doi. org/10.1016/j.micres.2007.06.002

El Bergadi F, Laachari F, Elabed S, Mohammed IH, Ibnsouda SK (2014) Cellulolytic potential and filter paper activity of fungi isolated from ancients manuscripts from the Medina of Fez. Ann Microbiol 64:815-822. https://doi.org/10.1007/s13213-013-0718-6

Florian ML (1996) The role of the conidia of fungi in fox spots + rusty irregularly shaped areas on rag paper in 16th-century to 19th-century books. Stud Conserv 41:65-67. https://doi.org/10. 2307/1506518

Florian M-LE, Manning L (2000) SEM analysis of irregular fungal spot in an 1854 book: population dynamics and species identification. Int Biodeterior Biodegrad 46:205-220

Florian M-LE (2002) Fungal facts: solving fungal problems in heritage collections. Archetype publications. London

Florian M-LE (2007) Protein facts. Fibrous proteins in cultural and natural history artifacts. Archetype Publications, London

Gallo F, Strzelczyk A (1971) Indagine preliminare sulle alterazioni microbiche della pergamena. Boll Ist Patol Libro 30:71-87

Green PWC, Farman DI (2015) Can paper and glue alone sustain damaging populations of booklice, Liposcelis bostrychophila? J Conserv Museum Stud 13:3 
Gu JD, Kigawa R, Sato Y, Katayama Y (2013) Addressing the microbiological problems of cultural property and archive documents after earthquake and tsunami. Int Biodeter Biodegr 85:345-346. https://doi.org/10.1016/j.ibiod.2013.08.018

Gutarowska B (2016) A modern approach to biodeterioration assessment and the disinfection of historical book collections. Lodz University of Technology

Hyde KD, Xu J, Rapior S et al (2019) The amazing potential of fungi: 50 ways we can exploit fungi industrially. Fungal Divers 97:1. https://doi.org/10.1007/s13225-019-00430-9

Jacobsen RM, Sverdrup-Thygeson A, Kauserud H, Birkemoe T (2018) Revealing hidden insectfungus interactions; moderately specialized, modular and anti-nested detritivore networks. Proc R Soc B 285:20172833. https://doi.org/10.1098/rspb.2017.2833

Jayasekara S, Ratnayake R (2019) Microbial cellulases: an overview and applications. In: Rodríguez Pascual A, Eugenio Martín ME (eds) Cellulose. IntechOpen, London. https://doi. org/10.5772/intechopen.84531.

Karakasidou K, Nikolouli K, Amoutzias GD, Pournou A, Manassis C, Tsiamis G, Mossialos D (2018) Microbial diversity in biodeteriorated Greek historical documents dating back to the 19th and 20th century: a case study. Microbiol Open 7:e00596. https://doi.org/10.1002/mbo3.596

Karbowska-Berent J, Strzelczyk A (2000) The role of streptomycetes in the biodeterioration of historic parchment. Nicolaus Copernicus University, Torun

Karbowska-Berent J, Jarmiłko J, Czuczko J (2014) Fungi in fox spots of a drawing by Leon Wyczółkowski. Restaurator 35:159-179. https://doi.org/10.1515/res-2014-1000

Koul B, Upadhyay H (2018) Fungi-mediated biodeterioration of household materials, libraries, cultural heritage and its control. In: Gehlot P, Singh J (eds) Fungi and their role in sustainable development: current perspective. Springer, Singapore, pp 597-615

Kraková L, Chovanová K, Selim SA, Šimonovičová A, Puškarová A, Maková A, Pangallo D (2012) A multiphasic approach for investigation of the microbial diversity and its biodegradative abilities in historical paper and parchment documents. Int Biodeter Biodegr 70:117-125. https://doi.org/10.1016/j.ibiod.2012.01.011

Kraková L, Šoltys K, Otlewska A, Pietrzak K, Purkrtová S, Savická D, Puškárová A, Bučková M, Szemes T, Budiš J, Demnerová K, Gutarowska B, Pangallo D (2018) Comparison of methods for identification of microbial communities in book collections: culture-dependent (sequencing and MALDI-TOF-MS) and culture-independent (Illumina MiSeq). Int Biodeter Biodegr 131:51-59. https://doi.org/10.1016/j.ibiod.2017.02.015

Larsen R (2002) Microanalysis of parchment. Archetype Publications, London

Lax S, Cardona C, Zhao D, Winton VJ, Goodney G, Gao P, Gottel N, Hartmann EM, Henry C, Thomas PM, Kelley ST, Stephens B, Gilbert JA (2019) Microbial and metabolic succession on common building materials under high humidity conditions. Nat Commun 10:1767. https://doi. org/10.1038/s41467-019-09764-z

Lazaridis M, Katsivela E, Kopanakis I, Raisi L, Mihalopoulos N, Panagiaris G (2018) Characterization of airborne particulate matter and microbes inside cultural heritage collections. J Cult Herit 30:136-146. https://doi.org/10.1016/j.culher.2017.09.018

Lech T (2016) Evaluation of a parchment document, the 13th century incorporation charter for the city of Krakow, Poland, for microbial hazards. Appl Environ Microbiol 82:2620-2631. https:// doi.org/10.1128/AEM.03851-15

Liao C-M, Luo W-C, Chen S-C, Chen J-W, Liang H-M (2004) Temporal/seasonal variations of size-dependent airborne fungi indoor/outdoor relationships for a wind-induced naturally ventilated airspace. Atmos Environ 38:4415-4419. https://doi.org/10.1016/j.atmosenv.2004.04. 029

Liu Z, Zhang Y, Zhang F, Hu C, Liu G, Pan J (2018) Microbial community analyses of the deteriorated storeroom objects in the Tianjin Museum using culture-independent and culturedependent approaches. Front Microbiol 9:802. https://doi.org/10.3389/fmicb.2018.00802

Mallo AC, Nitiu DS, Elíades LA, Saparrat MCN (2017) Fungal degradation of cellulosic materials used as support for cultural heritage. Int J Conserv Sci 8:619-632 
Marvasi M, Cavalieri D, Mastromei G, Casaccia A, Perito B (2019) Omics technologies for an indepth investigation of biodeterioration of cultural heritage. Int Biodeter Biodegr 144:104736. https://doi.org/10.1016/j.ibiod.2019.104736

Mazzoli R, Giuffrida MG, Pessione E (2018) Back to the past: "find the guilty bug-microorganisms involved in the biodeterioration of archeological and historical artifacts". Appl Microbiol Biotechnol 102:6393-6407. https://doi.org/10.1007/s00253-018-9113-3

Melo D, Sequeira SO, Lopes JA, Macedo MF (2019) Stains versus colourants produced by fungi colonising paper cultural heritage: a review. J Cult Herit 35:161-182. https://doi.org/10.1016/j. culher.2018.05.013

Michaelsen A, Pinzari F, Ripka K, Lubitz W, Piñar G (2006) Application of molecular techniques for identification of fungal communities colonising paper material. Int Biodeter Biodegr 58:133-141. https://doi.org/10.1016/j.ibiod.2006.06.019

Michaelsen A, Piñar G, Montanari M, Pinzari F (2009) Biodeterioration and restoration of a $16^{\text {th }}$ century book using a combination of conventional and molecular techniques: a case-study. Int Biodeter Biodegr 63:161-168. https://doi.org/10.1016/j.ibiod.2008.08.007

Michaelsen A, Piñar G, Pinzari F (2010) Molecular and microscopical investigation of the microflora inhabiting a deteriorated Italian manuscript dated from the 13th-century. Microb Ecol 60:69-80. https://doi.org/10.1007/s00248-010-9667-9

Micheluz A, Manente S, Tigini V, Prigione V, Pinzari F, Ravagnan G, Varese GC (2015) The extreme environment of a library: xerophilic fungi inhabiting indoor niches. Int Biodeter Biodegr 99:1-7. https://doi.org/10.1016/j.ibiod.2014.12.012

Micheluz A, Manente S, Rovea M, Slanzi D, Varese GC, Ravagnan G, Formenton G (2016) Detection of volatile metabolites of moulds isolated from a contaminated library. J Microbiol Methods 128:34-41. https://doi.org/10.1016/j.mimet.2016.07.004

Migliore L, Thaller MC, Vendittozzi G, Mejia AY, Mercuri F, Orlanducci S, Rubechini A (2017) Purple spot damage dynamics investigated by an integrated approach on a 1244 A.D. parchment roll from the secret Vatican archive. Sci Rep 7:9521. https://doi.org/10.1038/s41598-01705398-7

Migliore L, Perini N, Mercuri F, Orlanducci S, Rubechini A, Thaller MC (2019) Three ancient documents solve the jigsaw of the parchment purple spot deterioration and validate the microbial succession model. Sci Rep 9:1623. https://doi.org/10.1038/s41598-018-37651-y

Modica AMB, Di Bella M, Alberghina MF, Brai MDF, Tranchina L (2016) Characterization of foxing stains in early twentieth century photographic and paper materials. Nat Prod Res 33:987996. https://doi.org/10.1080/14786419.2016.1180600

Modica A, Bruno M, Di Bella M, Alberghina MF, Brai M, Fontana D, Tranchina L (2019) Characterization of foxing stains in early twentieth century photographic and paper materials. Nat Prod Res 33:987-996. https://doi.org/10.1080/14786419.2016.1180600

Montanari M, Melloni V, Pinzari F, Innocenti G (2012) Fungal biodeterioration of historical library materials stored in compactus movable shelves. Int Biodeter Biodegr 75:83-88. https://doi.org/ 10.1016/j.ibiod.2012.03.011

Nielsen KF (2002) Mould growth on building materials. Secondary metabolites, mycotoxins and biomarkers. PhD Thesis. BioCentrum-DTU, Technical University of Denmark.

Nielsen KF (2003) Review: Mycotoxin production by indoor molds. Fungal Genet Biol 39:103-117

Nol L, Henis Y, Kenneth RG (2001) Biological factors of foxing in postage stamp paper (Reprinted). Int Biodeterior Biodegradation 48:98-104. https://doi.org/10.1016/S0964-8305 (01)00072-5

Nosanchuk JD, Stark RE, Casadevall A (2015) Fungal Melanin: what do we know about structure? Front Microbiol 6:1463. https://doi.org/10.3389/fmicb.2015.01463

Nunes I, Mesquita N, Cabo Verde S, Leitao Bandeira AM, Carolino MM, Portugal A, Botelho ML (2013) Characterization of an airborne microbial community: a case study in the archive of the University of Coimbra, Portugal. Int Biodeter Biodegr 79:36-41. https://doi.org/10.1016/j. ibiod.2013.01.013 
Nunes M, Relvas C, Figueira F, Campelo J, Candeias A, Caldeira AT, Ferreira T (2015) Analytical and microbiological characterization of paper samples exhibiting foxing stains. Microsc Microanal 21:63-77. https://doi.org/10.1017/S143192761500001X

Oetari A, Susetyo-Salim T, Sjamsuridzal W, Suherman EA, Monica M, Wongso R, Fitri R, Nurlaili DG, Ayu DC, Teja TP (2016) Occurrence of fungi on deteriorated old dluwang manuscripts from Indonesia. Int Biodeter Biodegr 114:94-103. https://doi.org/10.1016/j.ibiod.2016.05.025

Paiva de Carvalho H, Mesquita N, Trovão J, Peixoto da Silva J, Rosa B, Martins R, Bandeira AML, Portugal A (2016) Diversity of fungal species in ancient parchments collections of the archive of the University of Coimbra. Int Biodeter Biodegr 108:57-66. https://doi.org/10.1016/j.ibiod. 2015.12.001

Pangallo D, Chovanova K, Simonovicova A, Ferianc P (2009) Investigation of microbica community isolated from indoor artworks and their environment: identification, biodegradative abilities, and DNA typing. Can J Microbiol 55:277-287. https://doi.org/10.1139/W08-136

Perini N, Mercuri F, Thaller MC, Orlanducci S, Castiello D, Talarico V, Migliore L (2019) The stain of the original salt: red heats on chrome tanned leathers and purple spots on ancient parchments are two sides of the same ecological coin. Front Microbiol 10:2459. https://doi.org/ 10.3389/fmicb.2019.02459

Petushkova JP, Koestler R (1996) Biodeterioration studies on parchment and leather attacked by bacteria in the Commonwealth of Socialist States. In: Federici C, Munafò PF (eds) International conference on conservation and restoration of archival and library materials. Erice, 22nd-29th April 1996. G.P. Palumbo, Palermo, pp 195-211

Piñar G, Sterflinger K, Pinzari F (2015a) Unmasking the measles-like parchment discoloration: molecular and microanalytical approach. Environ Microbiol 17:427-443. https://doi.org/10. $1111 / 1462-2920.12471$

Piñar G, Sterflinger K, Ettenauer J, Quandt A, Pinzari F (2015b) A combined approach to assess the microbial contamination of the Archimedes Palimpsest. Microb Ecol 69:118-134. https://doi. org/10.1007/s00248-014-0481-7

Piñar G, Tafer H, Sterflinger K, Pinzari F (2015c) Amid the possible causes of a very famous foxing: molecular and microscopic insight into Leonardo da Vinci's self-portrait. Environ Microbiol Rep 7:849-859. https://doi.org/10.1111/1758-2229.12313

Pinzari F (2011) Microbial ecology of indoor environments. The ecological and applied aspects of microbial contamination in archives, libraries and conservation environments. In: Abdul-Wahab SA (ed) Sick building syndrome in public buildings and workplaces. Springer, Berlin, pp $153-178$

Pinzari F (2018) Microbial processes involved in the deterioration of paper and parchment. In: Mitchell R, Clifford J (eds) Biodeterioration and preservation in art, archaeology and architecture. Archetype Publications, London, pp 33-56

Pinzari F, Montanari M (2008) A substrate utilisation pattern (SUP) method for evaluating the biodeterioration potential of micro -flora affecting libraries and archival materials. In: Joice H, Townsend L, Toniolo F, Cappitelli F (eds) Conservation science. Archetype Publications, London, pp 236-241

Pinzari F, Montanari M (2011) Mould growth on library materials stored in compactus-type shelving units. In: Abdul-Wahab SA (ed) Sick building syndrome in public buildings and workplaces. Springer, Berlin, pp 193-206

Pinzari F, Canhoto O, Fanelli C, Magan N (2004) Electronic nose for the early detection of moulds in libraries and archives. Indoor Built Environ 13:387-395. https://doi.org/10.1177/ 1420326 X04046948

Pinzari F, Pasquariello G, De Mico A (2006) Biodeterioration of paper: a SEM study of fungal spoilage reproduced under controlled conditions. Macromol Symp 238:57-66. https://doi.org/ 10.1002/masy.200650609

Pinzari F, Zotti M, De Mico A, Calvini P (2010) Biodegradation of inorganic components in paper documents: formation of calcium oxalate crystals as a consequence of Aspergillus terreus Thom growth. Int Biodeter Biodegr 64:499-505. https://doi.org/10.1016/j.ibiod.2010.06.001 
Pinzari F, Troiano F, Piñar G, Sterflinger K, Montanari M (2011) The contribution of microbiological research in the field of book, paper and parchment conservation. In: Engel P, Schirò J, Larsen R, Moussakova E, Kecskeméti I (eds) New approaches to book and paper conservationrestoration. Verlag Berger, Horn/Wien, pp 575-594

Pinzari F, Cialei V, Piñar G (2012a) A case study of ancient parchment biodeterioration using variable pressure and high vacuum scanning electron microscopy. In: Meeks N, Cartwright C, Meek A, Mongiatti A (eds) Historical technology, materials and conservation: SEM and microanalysis. Archetype Publications, London, pp 93-99

Pinzari F, Colaizzi P, Maggi O, Persiani AM, Schütz R, Rabin I (2012b) Fungal bioleaching of mineral components in a twentieth-century illuminated parchment. Anal Bioanal Chem 402:1541-1550. https://doi.org/10.1007/s00216-011-5263-1

Polo A, Cappitelli F, Villa F, Pinzari F (2017) Biological invasion in the indoor environment: the spread of Eurotium halophilicum on library materials. Int Biodeter Biodegr 118:34-44. https:// doi.org/10.1016/j.ibiod.2016.12.010

Principi P, Villa F, Sorlini C, Cappitelli F (2011) Molecular studies of microbial community structure on stained pages of Leonardo da Vinci's Atlantic Codex. Microb Ecol 61:214-222. https://doi.org/10.1007/s00248-010-9741-3

Puškárová A, Bučková M, Habalová B, Kraková L, Maková A, Pangallo D (2016) Microbial communities affecting albumen photography heritage: a methodological survey. Sci Rep 6:20810. https://doi.org/10.1038/srep20810

Ramsey MM, Freire MO, Gabrilska RA, Rumbaugh KP, Lemon KP (2016) Staphylococcus aureus shifts toward commensalism in response to Corynebacterium species. Front Microbiol 7:1230. https://doi.org/10.3389/fmicb.2016.01230

Rakotonirainy MS, Heude E, Lavedrine B (2007) Isolation and attempts of biomolecular characterization of fungal strains associated to foxing on a 19th century book. J Cult Herit 8:126-133. https://doi.org/10.1016/j.culher.2007.01.003

Ritz K (1995) Growth responses of some soil fungi to spatially heterogeneous nutrients. FEMS Microbiol Ecol 16:269-280. https://doi.org/10.1016/0168-6496(94)00090-J

Saada NS, Abdel-Maksound G, Youssef AM, Abdel-Aziz MS (2018) The hydrolytic activities of two fungal species isolated from historical quranic parchment manuscript. J Soc Leath Tech $\mathrm{Ch}$ 102:141-148

Sanmartín P, DeAraujo A, Vasanthakumar A (2018) Melding the old with the new: trends in methods used to identify, monitor, and control microorganisms on cultural heritage materials. Microb Ecol 76:64-80. https://doi.org/10.1007/s00248-016-0770-4

Sato YY, Aoki M, Kigawa R (2014) Microbial deterioration of tsunami-affected paper-based objects: a case study. Int Biodeter Biodegr 88:142-149. https://doi.org/10.1016/j.ibiod.2013.12. 007

Sawoszczuk T, Syguła-Cholewińska J, del Hoyo-Meléndez JM (2015) Optimization of headspace solid phase microextraction for the analysis of microbial volatile organic compounds emitted by fungi: application to historical objects. J Chromatogr A 1409: 30-45. doi:https://doi.org/10. 1016/j.chroma.2015.07.059

Sawoszczuk T, Syguła-Cholewińska J, del Hoyo-Meléndez JM (2017) Application of HS-SPMEGC-MS method for the detection of active moulds on historical parchment. Anal Bioanal Chem 409:2297-2307. https://doi.org/10.1007/s00216-016-0173-x

Sclocchi MC, Kraková L, Pinzari F, Colaizzi P, Bicchieri M, Šaková N (2016) Microbial life and death in a foxing stain: a suggested mechanism of photographic prints defacement. Microb Ecol 73:1-12. https://doi.org/10.1007/s00248-016-0913-7

Sterflinger K, Pinzari F (2012) The revenge of time: Fungal deterioration of cultural heritage with particular reference to books, paper and parchment. Environ Microbiol 14:559-566. https://doi. org/10.1111/j.1462-2920.2011.02584.x

Sterflinger K, Little B, Piñar G, Pinzari F, de los Rios A, Gu JD (2018) Future directions and challenges in biodeterioration research on historical materials and cultural properties. Int Biodeter Biodegr 129:10-12. https://doi.org/10.1016/j.ibiod.2017.12.007 
Szczepanowska H, Mathia TG, Belin P (2014) Morphology of fungal stains on paper characterized with multi-scale and multi-sensory surface metrology. Scanning 36:76-85. https://doi.org/10. 1002/sca.21095

Szczepanowska HM, Jha D, Mathia TG (2015) Morphology and characterization of Dematiaceous fungi on a cellulose paper substrate using synchrotron X-ray microtomography, scanning electron microscopy and confocal laser scanning microscopy in the context of cultural heritage. J Anal Atom Spectrom 30:651-657. https://doi.org/10.1039/c4ja00337c

Szulc J, Otlewska A, Ruman T, Kubiak K, Karbowska-Berent J, Kozielec T, Gutarowska B (2018) Analysis of paper foxing by newly available omics techniques. Int Biodeter Biodegr 132:157-165. https://doi.org/10.1016/j.ibiod.2018.03.005

Tanney JB, Nguyen HDT, Pinzari F, Seifert KA (2015) A century later: rediscovery, culturing and phylogenetic analysis of Diploöspora rosea, a rare onygenalean hyphomycete. Anton Leeuw Int J G 108:1023-1035. https://doi.org/10.1007/s10482-015-0555-7

Teasdale MD, Fiddyment S, Vnouček J, Mattiangeli V, Speller C, Binois A, Carver M, Dand C, Newfield TP, Webb CC, Bradley DG, Collins MJ (2017) The York Gospels: a 1000-year biological palimpsest. R Soc Open Sci 4:170988. https://doi.org/10.1098/rsos.170988

Treseder KK, Lennon JT (2015) Fungal traits that drive ecosystem dynamics on land. Microbiol Mol Biol Rev 79:243-262. https://doi.org/10.1128/MMBR.00001-15

Vaisanen OM, Weber A, Bennasar A, Rainey FA, Busse HJ, Salkinoja-Salonen MS (1998) Microbial communities of printing paper machines. J Appl Microbiol 84:1069-1084

Wang XW, Houbraken J, Groenewald JZ, Meijer M, Andersen B, Nielsen KF, Crous PW, Samson RA (2016) Diversity and taxonomy of Chaetomium and Chaetomium-like fungi from indoor environments. Stud Mycol 84:145-224. https://doi.org/10.1016/j.simyco.2016.11.005

Zotti M, Ferroni A, Calvini P (2008) Microfungal biodeterioration of historic paper: preliminary FTIR and microfungal analyses. Int Biodeterior Biodegradation 62:186-194. https://doi.org/10. 1016/j.ibiod.2008.01.005

Zotti M, Ferroni A, Calvini P (2011) Mycological and FTIR analysis of biotic foxing on paper substrates. Int Biodeterior Biodegradation 65:569-578. https://doi.org/10.1016/j.ibiod.2010.01. 011

Zyska B (1997) Fungi isolated from library materials: a review of the literature. Int Biodeter Biodegr 40:43-51. https://doi.org/10.1016/S0964-8305(97)00061-9

Open Access This chapter is licensed under the terms of the Creative Commons Attribution 4.0 International License (http://creativecommons.org/licenses/by/4.0/), which permits use, sharing, adaptation, distribution and reproduction in any medium or format, as long as you give appropriate credit to the original author(s) and the source, provide a link to the Creative Commons license and indicate if changes were made.

The images or other third party material in this chapter are included in the chapter's Creative Commons license, unless indicated otherwise in a credit line to the material. If material is not included in the chapter's Creative Commons license and your intended use is not permitted by statutory regulation or exceeds the permitted use, you will need to obtain permission directly from the copyright holder.

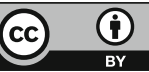

